\title{
Controle de Legitimidade das Políticas Públicas: Limites e Possibilidades
}

\author{
Farlei Martins Riccio de Oliveira'
}

\section{Introdução}

As políticas públicas no Brasil têm sido objeto de grande discussão doutrinária e jurisprudencial, não apenas em relação à possibilidade de controle jurídico e jurisdicional dos meios empregados e dos fins constitucionais a serem atingidos, mas, sobretudo, pela falta de participação direta do cidadão na sua definição, formação e implementação.

Nos Estados democráticos, as decisōes sobre políticas públicas surgem da avaliação de dois Poderes do Estado, o Legislativo e o Executivo. Nesse contexto, as instituições capazes de exercer influência sobre a formulação e operacionalização das decisões públicas, sob um aspecto político, são os partidos, os sindicatos, os agentes econômicos e as organizações privadas.

A participação direta dos cidadāos tem aplicação restrita na maioria dos países, especialmente no Brasil. A conseqüência é que os representantes eleitos passam a defender políticas muito diversas e até contraditórias àquelas prometidas no momento da eleição. E quando o governo detém uma base parlamentar majoritária, o Poder Legislativo acaba exercendo o papel de mero espectador das escolhas governamentais, sem contar que, em muitos casos, o Parlamento é ignorado pelo Executivo em questões fundamentais, como o controle da execução orçamentária.

1 Mestre em Direito da Administração Pública pela UGF. Doutorando em Direito do Estado (PUCRio). Professor de Direito Administrativo da Universidade Candido Mendes - Centro. Advogado da Uniāo. 
Por outro lado, considerando que as políticas públicas sāo indispensáveis à garantia e promoção dos direitos fundamentais, especialmente dos direitos sociais, bem como toda e qualquer política pública envolve gasto de recursos públicos limitados, será preciso então priorizar e escolher onde o dinheiro público disponível será investido. Além da definição genérica em que gastar, é preciso ainda decidir como gastar, tendo em conta os objetivos específicos que se deseja alcançar.

Porém, na realidade brasileira, não é incomum que uma parte considerável dessas escolhas deixe de atender às verdadeiras necessidades da população, ou, ainda, que as atenda de forma incompleta, precária e equivocada.

Exatamente para evitar esses abusos, bem como estabelecer um equilíbrio harmônico entre os Poderes do Estado, o ordenamento jurídico brasileiro coloca à disposição do Legislativo e do Judiciário, meios de controle político e jurídico da definição e implementação das políticas públicas pelo Executivo.

Quanto ao controle parlamentar, além daquele eminentemente político e financeiro, existe o controle das políticas públicas efetivado pela atuação dos partidos políticos no cotidiano da atividade legislativa.

Quanto à atuaçāo do Poder Judiciário, via de regra, o controle jurisdicional da Administração Pública abrange a fiscalização e a correção dos atos ilegais e, em determinadas circunstâncias, o controle de mérito praticado pelos órgãos do Executivo e dos demais poderes que exercem funçōes administrativas.

No entanto, como a definição e a formulação das políticas públicas envolvem escolhas políticas e de gestão financeira e orçamentária do Estado, a questāo principal relaciona-se à verificação da possibilidade de controle judicial nesse campo e, se possível o controle, a identificação dos limites e critérios a serem utilizados pelo juiz em sua decisão.

Nesse sentido, o presente trabalho pretende investigar, a partir das noções de poder político e direito de participação, até que ponto a influência direta do cidadão na definição e formulação das políticas públicas pode ser um fator de legitimidade das escolhas governamentais.

Por outro lado, pretende-se investigar a relação dos partidos políticos e dos programas de governos estabelecidos na plataforma partidária com a legitimidade das políticas públicas encaminhadas e votadas no Parlamento. Sob esse aspecto será feita uma análise da atuação individual do parlamentar, como também da relação institucional entre os partidos políticos que compõem a base aliada do Governo, no intuito de verificar até que ponto os vícios da representação políticopartidária afetam a implementação das políticas públicas.

Por fim, a pesquisa pretende investigar as possibilidades e limites do controle jurídico das políticas públicas pelos órgãos do Poder Judiciário. Para esse fim, serão analisados os fundamentos das principais correntes doutrinárias e a posição mais recente do Supremo Tribunal Federal sobre o terna. 


\section{Poder político, legitimidade e participação}

No seu sentido lato, denomina-se poder a possibilidade de eficazmente impor aos outros o respeito da própria conduta ou de traçar a conduta alheia. ${ }^{2}$ Poder político é a faculdade exercida por um povo de, por autoridade própria (não recebida de outro poder), instituir órgãos que exerçam o senhorio de um território e nele criem e imponham normas jurídicas, dispondo dos necessários meios de coaçāo. ${ }^{3}$

O poder nasce com o indivíduo, mas passa aos grupos e, afinal, ao Estado, pelo processo de institucionalização. A concentração de poder é um fenômeno espontâneo na sociedade, nascida da necessidade de atender a interesses que demandam escala metaindividual. São as concentrações de poder que, estabilizadas pelo consenso e pelo costume, levam ao surgimento das instituições políticas. Pelo fenômeno da representação, o poder passa a ser exercido por um ou alguns dos membros do grupo para atuar em nome de todos. ${ }^{4}$

Um interesse metaindividual cometido pelo ordenamento jurídico ao Estado caracteriza um interesse público. ${ }^{5}$ Segundo MARIA SYLVIA ZANELLA DI PIETRO, a expressão interesse público, em sentido amplo, constitui o gênero que compreende várias modalidades: "o interesse geral, afeto a toda a sociedade; o interesse difuso, pertinente a um grupo de pessoas caracterizadas pela indeterminação e indivisibilidade; e o interesse coletivo, que diz respeito a um grupo de pessoas determinadas ou determináveis". ${ }^{6}$

DIOGO DE FIGUEIREDO MOREIRA NETO define interesse público como "interesses coletivos gerais que a sociedade comete ao Estado para que ele os satisfaça, através de ação política juridicamente embasada ou através de ação jurídica politicamente fundada". ${ }^{7}$

2 CAETANO, Marcello. Manual de Ciência Política e Direito Constitucional. Coimbra: Almedina, 2003, p. 5.

3 CAETANO, Marcello. Op. cit., p. 130. O mesmo refere que a funçāo do poder político é a de subordinar os interesses particulares ao interesse geral, segundo princípios racionais de justiça traduzidos por um Direito Comum a todas as sociedades primárias englobadas na sociedade política. Op. cit, p. 9.

4 MARCELLO CAETANO define a representaçāo política como o "princípio jurídico em virtude do qual um ou alguns indivíduos exercem o poder político ou participam no seu exercício em lugar e em nome dos titulares do referido poder e de modo que os actos dos representantes sejam considerados provenientes da autoridade dos representados". Op. cit., p. 186.

5 Há quem faça a distinção entre interesse público primário e secundário. Para LUIS ROBERTO BARROSO: "O interesse público primário é a razão de ser do Estado e sintetiza-se nos fins que cabe a ele promover: justiça, segurança e bem-estar social. Estes são os interesses de toda a sociedade. $\mathrm{O}$ interesse público secundário é o da pessoa jurídica de direito público que seja parte em uma determinada relação jurídica - quer se trate da Uniāo, do Estado-membro, do Município ou das suas autarquias. Em ampla medida, pode ser identificado como o interesse do erário, que é o de maximizar a arrecadaçāo e minimizar as despesas." O Estado contemporâneo, os direitos fundamentais e a redefiniçāo da supremacia do interesse público. Prefácio. in SARMENTO, Daniel (org). Interesses públicos versus interesses privados: desconstruindo o princípio de supremacia do interesse público. Rio de Janeiro: Lumen Juris, 2005.

6 Discricionariedade Administrativa na Constituição de 1988. São Paulo: Atlas, 2001, p. 224.

Legitimidade e discricionariedade. Rio de Janeiro: Forense, 1998, p. 13. 
A captação política dos interesses da sociedade é imediata e define a legitimidade, enquanto a cristalizaçāo jurídica desses interesses é mediata e define a legalidade.

Para o mesmo autor, as dimensões e funçōes são bem distintas: o interesse público, antes ou depois de legislado, é sempre padrão de legitimidade, mas só o interesse público legislado alcança o padrão de legalidade. Em resumo, a legitimidade é muito mais ampla que a legalidade, simplesmente porque é impossível, em qualquer sociedade, que a lei defina exaustivamente todas as hipóteses do interesse público. ${ }^{8}$

Nestes termos, a legalidade passa a ser um referencial ético-jurídico (normas) enquanto a legitimidade e a licitude sāo referenciais ético-morais (valores). Sob esse referencial, contrasta-se a ação estatal com a vontade dominante na sociedade e retira-se a conclusão: legítima, se concorda, ou ilegítima, se não é com ela concordante.

Legalidade e legitimidade convergem para atendimento ao interesse público, detalhando e precisando, de várias formas e em vários níveis, o seu conteúdo em uma sociedade organizada.

Sob uma perspectiva habermasiana, o direito tem uma dimensão fática e de legitimidade. Segundo HABERMAS não basta a dimensão fática da validade do Direito para que ele se ponha como regulador/ordenador social, mais que isso, depende esta dimensão de uma base legítima de reconhecimento social da sua validade. De outra forma, implica reconhecer que o sistema jurídico que se encontra ancorado tão-somente em uma justificação lógico-formal (provido de legalidade positiva) pode não ser fruto da vontade geral da comunidade que alcança, impondo-se por argumentos não racionais (de força e do medo pelo castigo). ${ }^{9}$

Como a legitimidade possui uma estreita relação com o poder político, a crise deste reflete invariavelmente na captação dos interesses públicos e na legitimidade de ações governamentais. DIOGO DE FIGUEIREDO MOREIRA NETO refere alguns fatores ou causas de crise de legitimidade do poder político ocorridas no século passado: (i) a passagem da conotação subjetiva do poder para a institucionalização do poder (Rei/Estado), o que determinou a necessidade de representação política dos cidadãos (democracia representativa); (ii) a hipertrofia do Estado após a Segunda Guerra Mundial, levando a que o poder político se concentrasse demasiadamente e ganhasse autonomia e justificativa dissociada dos interesses

8 MOREIRA NETO, Diogo de Figueiredo. Op. cit., p. 14

9 LEAL, Rogério Gasta. Os pressupostos epistemológicos e filosóficos da gestāo de políticas públicas no Estado democrático de direito: uma perspectiva habermasiana. Revista de Direito Administrativo e Constitucional, Belo Horizonte, ano 4, n 15, jan./mar. 2004, p. 165-166. Consulte-se ainda sobre a teoria política de Habermas em DUTRA, Delamar Jose Volpato. A deduçāo do princípio da democracia em Habermas. Revista de Direito Constitucional e Internacional, Sāo Paulo, ano 13, n² 51, abr./jun. 2005. 
públicos; (iii) a burocracia e tecnocracia que distanciam os indivíduos e os grupos sociais secundários. ${ }^{10}$

Assim, diante desses fatores, a democracia representativa entra em crise, ${ }^{11}$ pois se revela insuficiente como instrumento de legitimação do poder político. Buscase então uma democracia participativa, semidireta ou substancial. ${ }^{12}$

Para ROBERTO AMARAL é impossível salvar a democracia representativa porque ela contém uma contradição em termos: a impossibilidade de uma representação legítima (seu pressuposto), isto é, não eivada de manipulação, pela exigência de instrumentos de mediação que se constituem, ao mesmo tempo, em incontornáveis instrumentos de defraudação da vontade-cidadã original. ${ }^{13}$

Para esse mesmo autor, a questão central da democracia participativa, direito de quarta geração, é tanto suprir a intermediação - inerente à democracia indireta quanto, e paralela e seqüencialmente, substituir a representação. Ela compreende a emergência, no cenário da política, com poder decisório, das instituiçōes populares e sociais das mais diversas índoles, cuja organização enseja e estimula. ${ }^{14}$

A análise das diversas teorias democráticas foge ao escopo da presente pesquisa, mas podem ser indicados os seguintes modelos e os respectivos autores representativos das teorias: democracia elitista (Joseph Schumpeter), democracia pluralista (Robert Dahl), democracia legal (Friedrich Hayek e Robert Nozik), democracia participativa (Carole Pateman, Nikos Poulantzas, C. B. Macpherson) e democracia deliberativa (Jürgen Habermas). ${ }^{15}$

10 "A própria hipertrofia do Estado e o surgimento de novos estamentos sociais estatais, como a burocracia e a tecnocracia, a primeira, marca do aparecimento do próprio Estado concentrador e, a segunda, do Estado interventivo e planejador, estão distanciando os individuos $e$ os grupos sociais secundários das decisōes que lhes dizem respeito." MOREIRA NETO, Diogo de Figueiredo. Direito da participação política. Rio de Janeiro: Renovar, 1992, p. 19.

11 MARCOS AUGUSTO PEREZ refere alguns problemas identificados pela ciência política quanto à democracia representativa: "(1) oligarquizaçāo dos partidos políticos; (2) excessiva profissionalização da política; (3) desinteresse dos eleitores pela participaçāo política; (4) incapacidade dos parlamentares para identificar e resolver os complexos problemas inerentes à atuaçāo estatal no domínio social e econômico; (5) falta de educação política dos eleitores, levando-os a optar mais emotiva do que racionalmente, no momento de escolha dos governantes; (6) dificuldade de contenção do abuso do poder econômico nas eleiçōes; (7) influência nociva dos meios de comunicação de massas; (8) personalizaçāo excessiva do processo eleitoral; (10) concentração de poderes nas mãos da burocracia do Executivo; (11) cerceamento do debate parlamentar mediante a edição de atos normativos com força de lei pelo Executivo." A administraf̧ão pública democrática. Belo Horizonte: Fórum, 2004, p. 31.

12 "A frustração com a incapacidade da democracia, enquanto regime político, de gerar bons governos, pode gerar uma reação antidemocrática, em que receitas oligárquicas ou populistas se alternariam para suprir a inanidade dos processos democráticos adotados." MOREIRA NETO, Diogo de Figueiredo. Direito da participaçāo política. Rio de Janeiro: Renovar, 1992, p. 31.

13 A democracia representativa está morta: viva a democracia participativa! In GRAU, Eros Roberto e GUERRA FILHO, Willis Santiago (Org.). Direito constitucional: estudos em homenagem a Paulo Bonavides. São Paulo: Malheiros, 2003, p. 46.

14 Op. cit, p. 48-49.

15 Para uma análise sucinta dos referidos modelos teóricos, consulte-se, por todos, NOBRE, Marcos. Participaçāo e deliberaçāo na teoria democrática: uma introduçāo. In COELHO, Vera Schattan P. e NOBRE, Marcos (Org.). Participaçāo e Deliberaçāo: teoria democrática e experiências institucionais no Brasil contemporâneo. São Paulo: 34. ed., 2004. 


\section{I.I O direito de participação política como instrumento de captação dos interesses públicos}

Na balizada opinião de DIOGO DE FIGUEIREDO MOREIRA NETO, a crise da democracia representativa é uma crise de legitimidade do poder político, cuja superação deveria começar por certos ajustes nas técnicas de participação política para que: (i) o sistema sociocultural gere espontaneamente a motivação à ação política (atitude política); (ii) o sistema político-jurídico canalize, facilmente, as ambigüidades e os conflitos; (iii) o sistema governamental processe e filtre celeremente as escolhas que deverão ser atendidas, com prioridade, por suas decisões normativas e administrativas.

Segundo o mesmo publicista:

Somente pela participação é possível garantir-se que o Governo venha a decidir, seja abstrata ou concretamente, de acordo com a vontade do povo. O ideal seria, portanto, que todos pudessem e efetivamente se dispusessem a participar diretamente, como se tem noticia, na breve e fulgurante democracia ateniense ou no Cantão de Uri, na Suíça. O possivel, entretanto, até agora, tem sido a prática preferencial da intermediação de representantes que, presumidamente, decidirão de acordo com a vontade do povo, seus mandantes - uma participação indireta.

Prossegue afirmando: "A opção da participação, portanto, deve ser entendida como uma busca da eficiência pela legitimidade, na medida em que a norma legitimada pelo consenso recubra a decisão de supremacia com o consentimento estimulante da cidadania interessada." 16

Nestes termos, a participação política atende ao que se convencionou denominar de accountability vertical ${ }^{17}$ ou responsividade social, ${ }^{18}$ dimensão ético-pragmática da ação política que complementa a já conhecida responsabilidade política.

A democracia participativa surge como uma forma de reforçar o controle social sobre a atuação estatal e torná-la associada ao papel de efetivação dos direitos fundamentais, objetivos do Estado de Direito em sua acepção material. Nas palavras de DIOGO DE FIGUEIREDO MOREIRA NETO:

16 MOREIRA NETO, Diogo de Figueiredo. Direito da participaf̧ão política. Rio de Janeiro: Renovar, 1992, p. 35-50.

A expressão é de origem anglo-saxã e significa a responsabilização que se desenvolve de uma estrutura a outra do Estado.

18 "Na verdade, tomada em seu sentido mais dilatado, a responsividade, tal como surgiu nos estudos sobre a participaçāo política, é princípio instrumental da democracia, uma vez que se destina a salvaguardar a legitimidade, ou seja, a conciliar a expressão da vontade popular, democraticamente recolhida, com a racionalidade pública. Por isso, apresentada como complemento atualizador da responsabilidade, a responsividade é a reação governamental, que deve ser a normalmente esperada e exigida, ante a enunciaçāo da vontade dos governados." MOREIRA NETO, Diogo de Figueiredo. Curso de direito administrativo, Rio de Janeiro: Forense, 2006, p. 85. 
A realização da democracia material se suporta na participação política, aberta aos cidadãos ou a quaisquer pessoas físicas ou jurídicas em todos os Poderes e órgãos constitucionalmente autônomos do Estado para que tenham acesso à informação, para que sejam admitidos a manifestar sua opinião e influir na formulação de políticas públicas, para que possam, em alguns casos, co-participar das decisões e, por último, mas não menos importante, para que estejam legitimados para deflagrar os instrumentos de controle da legalidade, de legitimidade e de licitude para tanto dispostos na ordem jurídica vigente. ${ }^{19}$

Para REINHOLD ZIPPELIUS a noção democrática de Estado exige a autodeterminação das pessoas no campo político.

Sendo o povo detentor primário do poder estatal e que o poder de todos os órgãos do Estado emana dele, "toda forma de exercício do poder estatal necessita - direta ou indiretamente - de legitimação democrática. [...] Portanto, a característica do processo democrático reside no fato de que o poder exercido sobre o povo é sustentado pelo consentimento deste - na prática, pelo consentimento da maioria. Esse consentimento não pode ser manipulado, devendo ser obtido a partir da livre formação de opinião. ${ }^{20}$

Por essa razão, DIOGO DE FIGUEIREDO MOREIRA NETO conceitua o direito de participação política como "o ramo do Direito Político que estuda as modalidades de expressão da vontade individual e coletiva na sociedade aptas a interferir, formal ou informalmente, nos processos de poder do Estado, especificamente em suas expressões legislativas, administrativa e judicial". ${ }^{21}$

Todavia, há situações fáticas e jurídicas que podem restringir ou mesmo inviabilizar o efetivo exercício do direito de participação política. Pode-se citar: a motivação do indivíduo para participação (conotação subjetiva); ${ }^{22}{ }^{23}$ a previsão

19 Juridicidade, pluralidade normativa, democracia e controle social. In: Fundamentos do estado de direito: estudos em homenagem ao Professor Almiro do Couto e Silva. São Paulo: Malheiros, 2005, p. $109-110$.

20 Introdução ao estudo do direito. Traduçāo Gercélia Batista de Oliveira Mendes. Belo Horizonte: Del Rey, 2006, p. 131-132.

21 MOREIRA NETO, Diogo de Figueiredo. Direito da participaçāo politica. Rio de Janeiro: Renovar, 1992, p. 62.

22 "Ora, para o aperfeiçoamento democrático, o estrato apolítico é o que mais importa, pois, por motivos diferentes, nele estāo os avessos à participaçāo. A atitude de inércia, ante a problemática do poder, seja ela a teórica seja a prática, característica desse estrato, provém de três motivos básicos: a falta de sensibilidade para com o político - os apáticos, que nāo sentem interesse; a falta de desejo de atuar politicamente - os abúlicos, cujo interesse não os motiva suficientemente para a açāo; e a falta de condições de atuar - os acráticos, aos quais falta capacidade de agir na prossecução de interesses políticos." MOREIRA NETO, Diogo de Figueiredo. Op. cit., p. 23.

23 Como um antídoto à apatia, ignorância e egoísmo, BRUCE ACKERMAN propōe a democracia coercitiva. Em suas palavras: "Para essa perspectiva, se a maioria das pessoas nāo leva a política nacional a sério, simplesmente devemos forçá-las a prestar atenção. Todos os dias, cada cidadão comum deveria ser compelido a passar uma ou duas horas discutindo acontecimentos correntes. Com o passar do tempo, isso os encorajaria a realizar julgamentos políticos razoáveis. E se as discussōes revelassem que as massas visam à proteçāo de interesses pessoais mesquinhos, talvez pudéssemos confiar em cidadāos especialmente 
no direito positivo de instrumentos de participação (conotação objetiva); obstáculos à eficiência administrativa, já que a adoção de procedimentos administrativos pode tornar mais lentos e caros os processos decisórios da Administração Pública $^{24}$ (conotação material); o seqüestro da Administração Pública por interesses setoriais, em detrimento das demais categorias de interesses existentes na sociedade, inclusive do próprio interesse público (Overintrusion e underprotection) $;{ }^{25}$ e o efeito conservador da participação política (conotação temporal), uma vez que os administrados do presente podem dificultar os projetos de transformação para o futuro, na medida em que os de hoje não serão beneficiados pelas obras e projetos concebidos para produzir efeitos no longo prazo, opondo resistência em arcar com os encargos decorrentes. ${ }^{26}$

Não é por outra razão que DIOGO DE FIGUEIREDO MOREIRA NETO afirma que a participação política como método para prosseguir o máximo de legitimidade será utilizada sempre que seja possível e aconselhável: possível, porque nem sempre será materialmente realizável; aconselhável, porque em certos assuntos continuará sendo absolutamente inafastável que o Estado decida na sua qualidade de garantidor dos superiores valores de convivência social, ou seja, para as soluções que demandem a sua autoridade.

A conclusão que se impōe nesse tópico é que os sistemas juspolíticos de alto consenso e participação maximizam a legitimidade e podem funcionar com baixo nível de coerção. Caminha-se para uma Administração Pública Comunicativa que segundo ROGÉRIO LEAL precisa "contar/construir o maior número possível de adesão social legítima, adquirida através de ações comunicativas permanentes (tensionais e conflituosas em face de tratar de interesses eventualmente distintos) com todos os agentes envolvidos e alcançados pelo exercício do poder político - institucionais ou não". ${ }^{27}$

habilitados envolvidos na vida pública, para mostrar aos seus compatriotas uma visão genuinamente nacional e de caráter público sobre os problemas da nação." Nós, o povo soberano: fundamentos do direito constitucional. Tradução de Mauro Raposo de Mello. Belo Horizonte: Del Rey, 2006, p. 328.

${ }^{24}$ Sobre esse condicionamento, aponta PATRICIA BAPTISTA a necessidade de conjugação das exigências de participaçāo e de eficiência: "Nem o processo decisório deverá ser estendido a ponto de diferir em excesso o momento da decisão, sacrificando desnecessariamente a eficiência administrativa, nem o reclamo de eficiência pode impedir a inserçāo de instrumentos participativos nos processos decisórios da Administração Pública. As situaçōes em que se dará a prevalência de um princípio sobre o outro somente poderão ser determinadas concretamente, diante das especificidades de cada caso, admitindo-se o sacrificio da participação em prol da eficiência apenas quando demonstrado, através de critérios técnicos de ponderaçāo de princípios, que aquela seja francamente desnecessária ou inadequada para o objetivo que se pretenda alcançar." Transformaçöes do direito administrativo. Rio de Janeiro: Renovar, 2003, p. 159.

25 Segundo PATRICIA BAPTISTA o perigo de intromissão excessiva dos interesses sociais mais organizados não é de todo insuperável: "Para afastar o risco da monopolização da vontade administrativa por interesses corporativos é indispensável, antes de tudo, que a Administração não seja considerada apenas mais um dentre os participantes do processo. Ao contrário, mostra-se necessário que esteja em condiçōes de 'captar interesses públicos e de eventualmente impô-los'." Op. cit., p. 165.

26 Op. cit., p. 167.

27 Os pressupostos epistemológicos e filosóficos da gestão de políticas públicas no estado democrático de direito: uma perspectiva habermasiana. Revista de Direito Administrativo e Constitucional, Belo Horizonte, ano 4, n. 15, jan./mar. 2004, p. 175. 


\subsection{Tipos de participação política}

A participação política admite vários critérios classificatórios, dentre eles: (i) subjetivo (distinguindo a pessoa do indivíduo, do cidadāo e a de ambos, das entidades representativas dos grupos sociais secundários, intitulados à participação); (ii) finalístico (diferenciando a participaçāo que visa à legitimidade, daquela que busca, restritamente, a legalidade do exercício do poder estatal); (iii) formalístico (alinhando, de um lado, a participação informal e, de outro, a formalmente instituída); (iv) conteudístico (distinguindo níveis crescentes de intensidade de participação: informação, influência, co-elaboração e co-decisão); (v) objetivo (distribuindo as modalidades de participação política entre as manifestações do fenômeno do poder político no Estado: destinação do poder, atribuição do poder, exercício do poder, distribuição do poder, contenção do poder e detenção do poder); e (vi) funcional (acompanhando a clássica tripartição dos poderes orgânicos do Estado: Legislativo, Executivo e Judiciário). ${ }^{28}$

Para o escopo da presente investigação, cabe detalhar a participação política pelo critério funcional, ou seja, tendo em conta os diversos institutos de participação na função legislativa, executiva e judiciária.

A participação na função legislativa é a mais antiga e, sem dúvida, a de maior importância, pois diz respeito à consentaneidade política das escolhas normativas fundamentais, isto é, à legitimidade finalística na norma legal. Formalmente se dá pela representação política e pela participação semidireta (plebiscito, referendo, iniciativa popular e recall). Informalmente, pelos canais de publicidade e diversas modalidades de influência, inclusive através do lobby parlamentar. ${ }^{29}$

A Constituição de 1988 prevê no art. 14 quatro modalidades de participação popular na função legislativa mediante sufrágio unviersal: o voto direto e secreto; o plebiscito; o referendo e a iniciativa popular de lei.

Na lição de JOSÉ AFONSO DA SILVA, o sufrágio pode ser entendido como:

um direito que decorre diretamente do princípio de que todo poder emana do povo, que o exerce por meio de representantes eleitos ou diretamente. Constitui a instituição fundamental da democracia representativa e é pelo seu exercício que o eleitorado, instrumento técnico do povo, outorga legitimidade aos governantes. ${ }^{30}$

A participação na função administrativa, já mais recente, é modalidade em rápida expansão, apresentando formas diversificadas, que têm sido desenvolvidas em vários países, para aproximar o administrado das decisões executivas, procurando torná-las cada vez mais legítimas. Pode ocorrer em qualquer dos campos da ati-

\footnotetext{
28 MOREIRA NETO, Diogo de Figueiredo. Direito de participaçāo politica. Rio de Janeiro: Renovar, 1992, p. 69-70.

29 MOREIRA NETO, Diogo de Figueiredo. Op. cit., p. 76-87.

30 Curso de direito constitucional positivo. São Paulo: Malheiros, 2007, p. 349.
} 
vidade administrativa do Estado: se externa, no exercício do poder de polícia, na prestação de serviços públicos, no ordenamento econômico, no ordenamento social e no fomento público, ou, se interna, na gestão de pessoal, bens e serviços. ${ }^{31}$

Podem-se classificar os institutos de participação popular na função administrativa quanto à força vinculante ou grau de poderes atribuídos aos administrados:

i) institutos de participação vinculante ou gestão participativa (conselhos deliberativos, ${ }^{32}$ referendo e plebiscito administrativo, ${ }^{33}$ eleição para funções de chefia e de direção); $;^{34}$

ii) institutos de participação não vinculante ou de técnica consultiva (audiência pública, ${ }^{35}$ consulta pública ${ }^{36}$ e orçamento participativo); $;{ }^{37}$

31 MOREIRA NETO, Diogo de Figueiredo. Direito de participação política. Rio de Janeiro: Renovar, 1992, p. 76-87. Consulte-se, ainda, GROTTI, Dinorá Adelaide Musetti. A participação popular e a consensualidade na administração pública. In MOREIRA NETO, Diogo de Figueiredo (Coord). Uma avaliação das tendências contemporâneas do direito administrativo. Rio de Janeiro: Renovar, 2003, p. 647-662.

32 "Conselhos deliberativos se caracterizam por serem órgāos colegiados, criados por lei, que contam, necessariamente, com a participaçāo de representantes da Administraçāo e representantes da sociedade, com a missão de tomar decisōes em assuntos cuja competência lhes tenha sido estendida." PEREZ, Marcos Augusto. A administração pública democrática. Belo Horizonte: Fórum, 2004, p. 142.

33 Plebiscito administrativo pode ser definido como "o procedimento de consulta popular aberto a todos os cidadāos, prévio a tomada de uma decisão administrativa, que vincula a Administração ao cumprimento de seu resultado". E referendo pode ser caracterizado como "o procedimento de consulta popular, posterior à tomada de uma decisão pela Administração Pública, cujo resultado condiciona a efetividade dessa decisão". PEREZ, Marcos Augusto. Op. cit., p. 154-155.

34 Esse é o instituto mais polêmico no direito brasileiro. O Supremo Tribunal Federal, em julgamento cautelar de constitucionalidade de diversas normas estaduais que disciplinavam a eleição para provimento de cargos de diretor de escola pública, entendeu, por maioria, que $O$ instituto da eleição contraria as prerrogativas inerentes ao exercício do Poder Executivo (ADI 490-AM, 123-SC e 640MG). PEREZ, Marcos Augusto. Op. cit., p. 157-159.

35 "É o instituto de participação popular na Administraçāo Pública, de caráter não vinculante, consultivo ou meramente opinativo, inserido na fase instrutória do processo decisório, consistente na realização de uma sessão pública aberta a todos os interessados e voltada ao esclarecimento e à discussāo de todos os aspectos e problemas envolvidos em uma determinada decisão administrativa." PEREZ, Marcos Augusto. Op. cit., p. 168

36 Instrumento pouco freqüente no Brasil e com origem na enquête do direito francês, consiste em "procedimento de divulgação prévia de minutas de atos normativos (de interesse geral), visando que, no prazo determinado pela Administraçāo, todos os eventuais interessados ofereçam críticas, sugestões de aperfeiçoamento ou peçam informaçōes e resolvam dúvidas a respeito". PEREZ, Marcos Augusto. Op. cit., p. 177.

${ }^{37}$ Orçamento participativo é um instituto de "participação popular na Administração Pública não vinculante, de consulta, ou meramente opinativo. [...] Tem o objetivo de preparar, sob a condução da Administração, o projeto de lei orçamentária enviado pelo Executivo ao Legislativo. Compreende a realizaçāo de seguidas audiências públicas, geralmente regionalizadas, por vezes acompanhadas da eleiçāo de representantes para diferentes conselhos deliber ativos." PEREZ, Marcos Augusto. Op. cit., p. 179. Consulte-se, ainda, VITALE, Denise. Democracia Direita e Poder Local: a experiêricia brasileira do orçamento participativo. In COELHO, Vera Schattan P.; NOBRE, Marcos (Org.). Participação e deliberação: teoria democrática e experiências institucionais no Brasil contemporâneo. São Paulo: 34. ed. 2004, p. 239-254, e MOREIRA NETO, Diogo de Figueiredo. Mutafães do direito administrativo. Rio de Janeiro: Renovar, 2007, p. 251-272. 
iii) instituto de participação autônoma e vinculante ${ }^{38}$ (organizações não governamentais, ${ }^{39}$ entidades de utilidade pública, ${ }^{40}$ serviços sociais autônomos, ${ }^{41}$ organizações sociais ${ }^{42}$ e corporações de fiscalização do exercício profissional); ${ }^{43}$

A Constituição de 1988 não adotou todos os institutos de participação acima classificados, mas impôs a adoção de outros em funções específicas executadas pela Administração Pública, podendo-se citar a título exemplificativo: art. 10 (participação dos trabalhadores e empregados nos colegiados dos órgãos públicos); art. 194, VII (organização do sistema estatal de previdência social); art. 29, X (planejamento municipal); art. 187 (planejamento da política agrícola); art. 198, III (organização do serviço público de saúde); art. 204, II (organização do serviço público de assistência social); art. 205 e 206, VI (serviço público de ensino); art. $216, \mathbb{S} 1^{\circ}$ (promoção e proteção do patrimônio cultural); art. 225 (defesa do meio ambiente); art. $227, \mathbb{1} 1^{\circ}$ (proteção da criança e do adolescente); art. $37, \mathbb{3} 3^{\circ}$ (prestação do serviço público) ${ }^{44}$

Por essa razão, MARCOS AUGUSTO PEREZ assevera que a participação popular na Administração Pública revela-se um verdadeiro princípio de organização implíito do ordenamento constitucional brasileiro, conectado ao princípio democrático, ao princípio do Estado de Direito e ao princípio da eficiência administrativa. É princípio de organização, pois implica na estruturação de processos de tomada

\footnotetext{
38 Os institutos de participação popular de caráter vinculante e autônomo também são conhecidos como "setor social autogerido" (J. J. GOMES CANOTILHO), "formas cooperativas de participação" (GARCÍA DE ENTERRİA) e institutos de "delegação atípica" (DIOGO DE F. MOREIRA NETO). Segundo este último publicista, a delegação é atípica porque a Administraçāo não necessita, efetivamente, transferi-la ao particular, mas somente reconhecer a atuação do particular como colaborador da Administração. MOREIRA NETO, Diogo de Figueiredo. Direito da participą̧āo política. Rio de Janeiro: Renovar, 1992, p. 136-138.

39 Organizaçōes nāo Governamentais "são pessoas jurídicas privadas, sem caráter lucrativo, criadas por particulares e que podem vir a realizar atividades de interesse público, coincidentes, portanto, com atividades inerentes à função administrativa do Estado". PEREZ, Marcos Augusto. A Administraçāo pública democrática. Belo Horizonte: Fórum, 2004, p. 187.
}

40 Entidades de utilidade pública "são pessoas jurídicas privadas, corporativas ou fundacionais, sem finalidade lucrativa, que realizam atividades de interesse público e que possuem uma titulação, ou 'qualificação jurídica', reconhecida pela Administração, que lhes dá 'beneficios tributários e vantagens administrativas diversas". PEREZ, Marcos Augusto. Op. cit., p. 188-189.

41 Serviços sociais autônomos são as "pessoas jurídicas privadas que colaboram com a Administraçāo Pública, desempenhando, sem finalidade lucrativa, atividades de interesse público, tais como assistência social, formação profissional, serviços de saúde, ensino regular, entre outras". PEREZ, Marcos Augusto. Op. cit., p. 190.

42 Sāo pessoas jurídicas de direito privado, sem fins lucrativos, cujas atividades sejam dirigidas ao ensino, à pesquisa cientifica, ao desenvolvimento tecnológico, à proteção e preservação do meio ambiente etc. Consulte-se a Lei $n^{\circ} 9.637 / 98$.

43 Face ao novo regime jurídico dessas entidades instituído pela Lei $n^{\circ} 9.649 / 98$, bem como as disposiçōes da Lei $n^{\circ} 8.906 / 94$, que regulamenta a Ordem dos Advogados do Brasil, a definição encontra-se prejudicada diante do excessivo hibridismo do regime jurídico.

44 BAPTISTA, Patrícia. Transformaçōes do direito administrativo. Rio de Janeiro: Renovar, 2003, p. 152-155. 
de decisão pela Administração Pública ou de divisão de tarefas entre a Administração e os administrados, de modo a convocar estes últimos à execução direta de determinadas funções administrativas..$^{45}$

E, por fim, a participação na função judicial enriqueceu-se na medida em que novos interesses passaram a ser considerados como dignos de tutela judicial e as acrescidas modalidades de legitimação processual multiplicaram as possibilidades de suscitar a proteção de antigos e novos interesses. Admitem-se duas modalidades básicas de participação: primeiro, a mais significativa, pelo direito de ação, em geral, e em especial, quando referido a finalidades metaindividuais, e, segundo, pela ocasional ou permanente, em órgãos de jurisdição. ${ }^{46}$

\section{Políticas públicas: definição e formação}

A definição das políticas públicas caracteriza-se como uma função política do Estado. Segundo MARCELLO CAETANO, o princípio fundamental da função política é o interesse geral. A característica do seu exercício é a liberdade de op̧̧ão entre várias soluçōes possíveis. Quem governa, segundo o autor, opta. Ao traçar certa orientação ou ao adotar certo plano, escolhe uns caminhos e rejeita outros.

Assim, a função política pode ser definida, de acordo com MARCELLO CAETANO, como a "actividade dos órgãos do Estado cujo objecto directo e imediato é a conservação da sociedade política e a definição e prossecução do interesse geral mediante a livre escolha dos rumos ou das soluçōes consideradas preferíveis". ${ }^{47}$

No sentido amplo, política pública pode ser considerada o "resultado de uma atividade de autoridade regularmente investida de poder público e de legitimidade governamental, ou como um conjunto de práticas e normas que emanam de um ou de vários atores políticos". Em sentido estrito, se caracteriza "como o processo de escolha dos meios para se atingir os objetivos de uma administração, envolvendo a participação de agentes públicos e privados, ainda que esteja materializada através de um plano de ações, que tem a lei como instrumento normativo". ${ }^{48}$

As definições de políticas públicas relacionam-se com o perfil institucional de cada Estado. Nos Estados democráticos, as decisões surgem da avaliação de, pelo menos, dois poderes, o Legislativo e o Executivo. Nesse contexto, as instituições capazes de exercer influência sobre a formulação e operacionalização das decisões públicas, sob um aspecto político, são os partidos, os sindicatos de trabalhadores, as grandes empresas e as organizaçōes privadas.

\footnotetext{
15 A Administraçāo pública democrática. Belo Horizonte: Fórum, 2004, p. 83-84.

4. MOREIRA NETO, Diogo de Figueiredo. Direito da participação política. Rio de Janeiro: Renovar, 1992, p. 76-91.

4: Manual de ciência política e direito constitucional. Coimbra: Almedina, 2003, p. 172. Sobre a noçāo de ato político ou ato de governo no direito inglês e norte-americano, consulte-se MEDAUAR, Odete. Ato de governo. Revista de Direito Administrativo, Rio de Janeiro, 191:67-85, jan./mar. 1993.
}

78 DAL BOSCO, Maria Goretti. Discricionariedade em políticas públicas. Curitiba: Juruá, 2007, p. 245-247. 
Já a participação direta dos cidadãos tem aplicação restrita na maioria dos países. A conseqüência é que os representantes eleitos passam a defender políticas muito diversas e até contraditórias àquelas prometidas no momento da eleição. $\mathrm{E}$ quando o governo detém uma base parlamentar majoritária, o Poder Legislativo acaba exercendo o papel de mero expectador das escolhas governamentais, sem contar que, em muitos casos, o Parlamento é ignorado pelo Executivo em questões fundamentais, como o controle de execução orçamentária ou a aprovação do envolvimento do país em operações militares. ${ }^{49}$

Esse quadro leva ao que se convencionou denominar de "democracia elitista" ou "crise de governabilidade". ${ }^{50}$ Daí a razão pela qual o reforço da participação política nas funções legislativas e administrativas do Estado revela-se importante, incrementando uma democracia participativa real, que objetiva a busca de legitimidade das escolhas e decisōes governamentais.

\section{Segundo MARIA GORETTI DAL BOSCO:}

A interferência do administrado na definição das ações da Administração, além de tudo, proporciona o desenvolvimento de um senso de maior responsabilidade entre os funcionários e agentes públicos, porque impõe certa despolitização das decisões, evitando escolhas prejudiciais aos interesses de todos, estimulando a inovação nas práticas administrativas e criando um maior comprometimento dos cidadāos com as escolhas que ajudaram a fazer; promove, ainda, em maior medida, o princípio da igualdade e transforma o cidadāo no eixo de toda a atuação administrativa. ${ }^{51}$

No Brasil, o direito de participação do administrado nas políticas públicas encontra inúmeras barreiras para sua efetivação, sendo que estas são basicamente de natureza cultural, já que a democracia encontra-se em fase de aperfeiçoamento após o longo período de ditadura militar.

Por outro lado, há certa letargia da cidadania brasileira na medida em que subutiliza os instrumentos de participação popular, como faz referência ROGÉRIO LEAL:

Apesar de todo este arsenal cívico à disposição da cidadania brasileira, ele não raro é subutilizado, haja vista a letargia social pela qual esta cidadania passa, assistindo ao espetáculo da cena política nacional como mero espectador, fomentado inclusive pelo comportamento autoritário e endógeno dos poderes instituídos que, por vezes, crêem em sua auto-suficiência gerencial e política, ensejando uma relação artificial e de distanciamento de sua base soberana - a comunidade que deveria servir. ${ }^{52}$

49 DAL BOSCO, Maria Goretti. Op. cit., p. 249-250.

so PISARELLO, Gerardo apud DAL BOSCO, Maria Goretti. Op. cit., p. 251.

5 DAL BOSCO, Maria Goretti. Op. cit., p. 252.

52 O controle social dos serviços públicos no Brasil como condiçāo de sua possibilidade. Revista de Direito Administrativo e Constitucional, Belo Horizonte, ano 3, $n^{\mathbf{9}}$ 13, jul./set. 2003, p. 158. 
No direito positivo brasileiro, as decisões sobre políticas que abrangem os principais investimentos no país são tomadas através do Plano Plurianual, da Lei de Diretrizes Orçamentárias e do Orçamento Anual, sendo de competência privativa do Executivo a sua elaboração e envio ao Congresso Nacional (art. 84, XXII, da Constituição Federal) ${ }^{53}$ A participação dos cidadãos na fase de elaboração orçamentária é muito restrita, ocorrendo mais nos níveis dos diversos conselhos consultivos em vários setores da Administração. A exceção é o orçamento participativo, experiência adotada em Porto Alegre, Recife, São Paulo e outros municípios menores. ${ }^{54}$

Diante de todo o exposto, pode-se inferir que a participação popular revelase um eficiente instrumento de controle das políticas públicas, especialmente no que tange ao correto direcionamento dos recursos, os quais serão aplicados de acordo com as necessidades reais da população, contribuindo para uma maior racionalidade e eficiência na sua definição. De igual modo, para que essa realidade possa ser alcançada, faz-se necessário um maior investimento da Administração Pública na qualificação técnica de recursos humanos que possam compreender e organizar dados e informações com antecedência necessária para promover o bom desempenho das políticas públicas que serão implantadas.

\section{Controle das políticas públicas}

Considerando que a formulação e efetivação das políticas públicas se inserem no âmbito de competência do legislador e do administrador público, embora vinculado à previsão de uma lei orçamentária anual e a determinadas áreas expressamente previstas (educação e saúde, por exemplo), não há dúvida de que remanesce para essas autoridades do Estado uma competência discricionária. Essa margem de liberdade na escolha das atividades nas quais serão empregados os recursos públicos fundamenta-se no fato de se tratar de uma funçāo eminentemente política.

No Estado Democrático de Direito as políticas públicas são indispensáveis para a garantia e promoção dos direitos funúamentais, especialmente os direitos sociais. Mas o fato é que toda e qualquer política pública envolve gasto de dinheiro público, e os recursos públicos são limitados. ${ }^{55}$ Será preciso então priorizar e esco-

\footnotetext{
53 Refere MARIA PAULA DALLARI BUCCI que há, no entanto, políticas públicas que se traduzem em programas de açāo, em sentido estrito, como o Programa de Material Escolar, o Programa do Álcool, cujo detalhamento se exprime por meio de formas normativas infralegais, como decretos, portarias, resoluçōes, resultados da atividade regulamentar do Pode Executivo. Políticas públicas e direito administrativo. Revista de Informação Legislativa, Brasília, ano 34, n² 133, jan./mar. 1997.

if Segundo MARIA GORETTI DAL BOSCO, as experiências com o orçamento participativo têm merecido críticas sob vários aspectos, principalmente em razāo de restriçōes aos poderes do Legislativo, falta de cumprimerito das decisões tomadas durante a elaboração e as distorçōes de legitimidade nos instrumentos utilizados para realização das assembléias, como o costume de oferecer transporte e levar grande número de eleitores para as plenárias deliberativas, apenas para conseguir o apoio das representaçōes para determinadas lideranças. Discricionariedade em políticas públicas. Curitiba: Juruá, 2007, p. 296-297.

55 A principal limitação que se impõe no tocante à definição de políticas públicas tem sido a alegaçāo da reserva do possível, teoria surgida na Alemanha e amplamente utilizada nos países europeus,
} 
lher onde o dinheiro público disponível será investido. Além da definição genérica em que gastar, é preciso ainda decidir como gastar, tendo em conta os objetivos específicos que se deseja alcançar.

Essas decisões configuram o que CASS SUNSTEIN e STEPHEN HOLMES ${ }^{56}$ denominam escolhas trágicas, uma vez que a escassez de recursos econômicos e financeiros públicos impedem a realização de todos os objetivos sociais, de tal sorte que a realização de alguns desses relevantes objetivos impõe necessária e inevitavelmente o sacrificio de outros, igualmente importantes. ${ }^{57}$

Porém, na realidade brasileira, nāo é incomum que uma parte considerável dessas escolhas deixe de atender às verdadeiras necessidades da populaçāo, ou, ainda, que as atenda de forma incompleta, precária e equivocada. Mas não é só, há ocasiōes em que a Administração acaba por realizar açōes que não seguem os princípios da eficiência e moralidade, como as previsōes orçamentárias superestimadas ou subestimadas, patrocinando verdadeiros cemitérios de obras inacabadas, ou, ainda, preferem aplicar os recursos em iniciativas que "aparecem", como obras físicas, deixando de cumprir com as obrigações determinadas na Constituição. ${ }^{58}$

Exatamente para evitar esses abusos, bem como estabelecer um equilíbrio harmônico entre os Poderes do Estado, o ordenamento jurídico brasileiro coloca à disposição do Legislativo e do Judiciário, meios de controle político e jurídico da definição e implementação das políticas públicas pelo Executivo. ${ }^{59,60}$

segundo a qual a prestação reclamada pelo administrado deve corresponder ao que o indivíduo pode, razoavelmente, exigir da sociedade, de modo que, ainda que o Estado disponha de recursos e poder de disposição, não há obrigatoriedade de prestar algo que sobressai aos limites do razoável. Sobre esse tema, consulte-se, por todos, KRELL, Andréas. Direitos sociais e controle judicial no Brasil e na Alemanha: os (des)caminhos de um direito constitucional comparado. Porto Alegre: Sergio Fabris, 2002.

56 HOLMES, Stephen e SUNSTEIN, Cass. The cost of rights. Cambridge: Harvad University Press, 1999, apud GALDINO, Flávio. O custo dos direitos. in TORRES, Ricardo Lobo. Legitimaçāo dos direitos humanos. Rio de Janeiro: Renovar, 2007.

57 Ainda segundo os mesmos autores, o óbice da exaustão orçamentária para realização dos direitos sociais presta-se unicamente a encobrir as trágicas escolhas que deixaram de fora do universo do possível a tutela de um determinado direito, já que os recursos públicos são captados em caráter permanente - a captação nunca cessa, de forma que, a rigor, nunca são completamente exauridos. Assim sendo, nada obstaria a que um outro orçamento posterior assumisse a despesa em questão. GALDINO, Flávio. O custo dos direitos. In TORRES, Ricardo Lobo. Legitimação dos direitos humanos. Rio de Janeiro: Renovar, 2007, p. 283-284.

58 DAL BOSCO, Maria Goretti. Discricionariedade em políticas públicas, Curitiba: Juruá, 2007, p. 320-321.

59 A divisão de poderes, como princípio institucional, é fenômeno que se opera no século XVIII. Segundo MONTESQUIEU para que o homem que detém o poder não possa abusar dele é preciso que, pela disposição das coisas, o poder freie o poder. Em cada Estado, prossegue o autor, há três espécies de poderes: o poder legislativo, o poder executivo das coisas que dependem do direito das gentes, e o executivo dos que dependem do direito civil. Pelo primeiro, o príncipe ou magistrado faz leis para certo tempo ou para sempre e corrige ou ab-roga as que estão feitas. Pelo segundo, faz a paz ou a guerra, envia ou recebe embaixadas, estabelece a segurança, previne as invasões. Pelo terceiro, pune os crimes ou julga as querelas dos indivíduos. Esse último é denominado de poder de julgar e o outro, simplesmente o poder executivo do Estado. Do espírito das leis. São Paulo: Abril, 1973, p. 155-162.

so Os princípios apresentados por MONTESQUIEU encontram-se, também, na obra de JOHN LOCKE, Segundo tratado sobre o governo. São Paulo: Abril, 1973, p. 97-103. Nessa obra LOCKE separa os poderes do Estado em Poder Legislativo, Executivo e Federativo da Comunidade. O Poder Legislativo é o que 


\section{I Controle parlamentar}

O controle político dos atos e contratos do Poder Executivo pelo Parlamento pode ter duas modalidades: o controle da função administrativa e o controle financeiro.

O controle político da função administrativa pode ocorrer nos seguintes casos: sustação de atos (CF, art. 49, V) e contratos do Executivo (CF, art. $71, \mathbb{\$} 1^{\circ}$ );

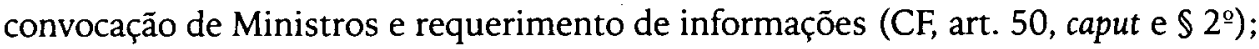
recebimento de petições, reclamações, de qualquer pessoa contra ato de omissão de qualquer entidade pública (CF, art. $58, \$ 2^{\circ}$, IV); solicitação de depoimento de qualquer pessoa ou autoridade (CF, art. $\left.58, \mathbb{} 2^{\circ}, \mathrm{V}\right)$; instalação de Comissão Parlamentar de Inquérito $\left(\mathrm{CF}\right.$, art. $\left.58, \$ 3^{\circ}\right)$; autorização ou aprovação do Congresso para atos concretos do Executivo (CF, art. 49, I, XII, XIII, XVI e XVII); poderes controladores privativos do Senado (CF, art. 52, III a IX); julgamento das contas do Executivo (CF, art. 49, IX c.c. 51, II c.c. 57) e suspensão e destituição do Presidente e Ministros por crimes de responsabilidade (CF, arts. 85 e 86 c.c. Lei no ${ }^{\circ}$ 1.079/50).

$O$ controle da Administração Financeira é aquele exercido quanto às finanças públicas de um modo geral (receita, despesa, gestão de recursos públicos), abrangendo todos os Poderes da República, direta e indireta (CF, art. 70) e todas as pessoas políticas (CF, art. 31 e 75), sendo exercido com o auxílio do Tribunal de Contas. ${ }^{61}$

Outra possibilidade de controle parlamentar é aquele exercido pelas atividades dos partidos políticos no cotidiano da função legislativa. Sendo o Parlamento composto por cidadãos eleitos em decorrência de um sufrágio universal e sendo o mandato político o instrumento da vontade popular, os partidos políticos desempenham na democracia participativa um importante papel de organização intermédia da sociedade. Pode, diante disso, controlar as atividades parlamentares dos eleitos, e por via indireta, as políticas públicas estabelecidas no programa de governo que serão votadas e aprovadas.

No entanto, esses mecanismos inerentes de controle político e financeiro não têm permitido assegurar um eficiente sistema de responsividade mútua dos Poderes do Estado, acarretando uma fraca fiscalização do Executivo pelo Legislativo.

tem o direito de estabelecer como se deverá utilizar a força da comunidade no sentido de preservação dela própria e do seus membros. Diz que esse poder não precisa estar permanentemente em exercício, uma vez que as leis podem ser elaboradas em curto espaço de tempo e também para se evitar a isençāo de subordinação às leis que fazem. Em seguida, apresenta as razōes para a separação do Poder Legislativo e Executivo. Nesse contexto o Poder Executivo seria um poder permanente que tem por finalidade acompanhar a execução das leis que se elaboram e ficam em vigor. Anote-se que não há no Tratado de Locke, nitidamente, uma separaçāo de poderes, mas uma certa organicidade e funcionalidade a respeito do poder político.

61 Consulte-se, por todos, TORRES, Ricardo Lobo. Controles da administração financeira. In MOREIRA NETO, Diogo de Figueiredo (Coord.). Uma avaliação das tendências contemporâneas do direito administrativo. Rio de Janeiro: Renovar, 2003, p. 635-646. 
Basta indicar, a titulo exemplificativo, alguns dados estatísticos apresentados por ARGELINA CHEIBUB FIGUEIREDO ${ }^{62}$ que evidenciam essa deficiência no sistema de freios e contrapesos do sistema brasileiro.

Em matéria de Comissōes Parlamentares de Inquérito (CPI), que deveriam ser instrumento de imposição de sanções ou de correções em políticas públicas, todo o processo de constituição e operação é permeado de conflitos políticos e manobras estratégicas, tanto de parlamentares, agindo individualmente, como dos líderes partidários. Freqüentemente, os propositores de uma CPI não pretendem realizar um inquérito e sim utilizá-la como moeda de troca política ou como parte de uma estratégia de um político em particular.

No período de 1946 a 1999, 392 CPIs foram propostas na Câmara dos Deputados, o que corresponde, em média, a mais de uma a cada dois meses. Dessas propostas, $77 \%$ (303) foram instaladas e $23 \%$ (89) não instaladas. Das que foram instaladas, $53 \%$ (207) foram concluídas, $23 \%$ (91) não concluídas. ${ }^{63}$

Quanto à fiscalização das contas públicas federais, os relatórios do Tribunal de Contas da União são geralmente favoráveis, com críticas apenas pontuais, e são apresentadas no prazo regulamentar, mas a aprovação do Congresso às vezes ocorre muito tempo depois da publicaçāo do relatório, e sempre por unanimidade. Não é incomum que as contas do governo sejam aprovadas após o encerramento do mandato do Presidente. Por razōes políticas, as recomendações contidas nos relatórios preparados pelo pessoal técnico deixam, geralmente, de ser seguidas pelo colegiado de Ministros. ${ }^{64}$

No julgamento de crimes de responsabilidade (processo de impeachment) apenas o caso do Presidente Collor de Mello em 1992 foi concluído. Ainda não ocorreu nenhum afastamento do mandato eletivo de um Ministro de Estado como resultado de um processo de impeachment..$^{65}$

De igual modo, a prerrogativa de sustar os atos do Poder Executivo que exorbitem do poder regulamentar jamais foi usada pelo Congresso. ${ }^{66}$

Esses são apenas alguns exemplos indicativos da ineficiência do controle parlamentar, especialmente no que se refere à execução de políticas públicas pelo governo.

Todavia, diante do objetivo que se pretende alcançar com a presente pesquisa, cabe uma breve análise das atribuições e funções dos partidos políticos no sistema de controle parlamentar, a fim de se identificarem as possibilidades de controle por essa via institucional.

62 Instituiçōes e política no controle do executivo. Revista de Ciências Sociais, Rio de Janeiro, v. 44, n ${ }^{9}$ 4, 2001, p. 689-727.

63 FIGUEIREDO, Argelina Cheibub. Op. cit., p. 696.

64 FIGUEIREDO, Argelina Cheibub. Op. cit., p. 710.

65 FIGUEIREDO, Argelina Cheibub. Op. cit., p. 714

66 FIGUEIREDO, Argelina Cheibub. Op. cit., p. 715. 


\subsection{A função dos partidos políticos e dos programas de governo}

$\mathrm{Na}$ democracia representativa, o voto é o instrumento essencial, através do qual o povo pode escolher aqueles que irão exercer o poder em seu nome. Entretanto, essa escolha deve estar amparada em determinados valores, princípios e programas.

Segundo CÍNTHIA ROBERT e JOSE LUIZ QUADROS MAGALHÃES, "para o funcionamento perfeito da democracia representativa, é essencial a existência dos partidos políticos fortes, com programas definidos. O eleitor moderno não pode mais confiar nas promessas de candidatos não comprometidos com a fidelidade a um programa e a um partido". ${ }^{67}$

No mesmo sentido ROBERTO AMARAL:

O partido político, livre, apto à alternância no poder, é o supra-sumo do pluralismo, e é através da solidez do sistema de partidos que se mede a robustez da democracia representativa. Portanto, sem o concurso dos partidos, essa ficção da realidade brasileira, não há como organizar e desempenhar as funçōes estatais. Na democracia representativa não há poder político se não há partido político. ${ }^{68}$

JOSÉ AFONSO DA SILVA assevera ser o partido político "uma forma de agremiação de um grupo social que se propõe organizar, coordenar e instrumentar a vontade popular com o fim de assumir o poder para realizar seu programa de governo". ${ }^{69}$

Em sua origem os partidos políticos eram vistos como óbices ao regime democrático, pois se acreditava que eles enfraqueciam a administração do Estado e eram barreiras quase que intransponíveis entre eleitos e eleitores. Com o desenvolvimento e aperfeiçoamento da democracia participativa, os partidos políticos evoluíram e passaram à condição de importante instrumento de participação popular na função legislativa. ${ }^{70}$

AUGUSTO ARAS ${ }^{71}$ aponta como elementos que imprimem características existenciais aos partidos políticos: o grupo social; a relaçāo de solidariedade entre seus membros e a disposição competitiva com os grupos diferentes; o programa político e a organização estável.

\footnotetext{
Teoria do Estado, democracia e poder local. Rio de Janeiro: Lumen Juris, 2002, p. 140.

68 A democracia representativa está morta: viva a democracia participativa! In GRAU, Eros Roberto e GUERRA FILHO, Willis Santiago (Org.). Direito constitucional: estudos em homenagem a Paulo Bonavides. São Paulo: Malheiros, 2003, p. 41.

69 Curso de direito constitucional positivo. São Paulo: Malheiros, 2007, p. 394.

70 ROBERT, Cínthia e MAGALHĀES, José Luiz Quadros de. Teoria do Estado, democracia e poder local. Rio de Janeiro: Lumen Juris, 2002, p. 141-150.

71 Fidelidade partidária: a perda do mandato parlamentar. Rio de Janeiro: Lumen Juris, 2006, p. 119.
} 
O programa político do partido enuncia as teses e ideologias, as propostas e as diretrizes que devem direcionar a ação partidária na busca pela conquista do poder e no seu exercício, sendo o amálgama que mantém a unidade e a coesão partidárias, resultante da affectio societatis geradora da aglutinação de indivíduos diferentes e integrantes de classes sociais heterogêneas. ${ }^{72}$

No direito brasileiro, os partidos políticos tiveram sua primeira regulamentação pelo Decreto $\mathrm{n}^{\circ} 21.076 / 32$, que instituiu o primeiro Código Eleitoral, tendo sido reconhecido, posteriormente, na Constituição Federal de 1934.

A atual Constituição Federal dispōe sobre os partidos políticos no capítulo dos direitos e garantias fundamentais, reconhecendo a sua natureza de pessoa jurídica de direito privado (art. $17, \$ 2^{9}$ ). Atualmente, os partidos políticos encontram-se regulamentados pela Lei $n^{0}$ 9.096/95.

A função primordial dos partidos políticos reside na organização da vontade popular, que deverá resultar na conquista do poder, visando à aplicação de seu programa de governo, devendo estruturar-se à vista de uma ideologia definida e com um programa de ação destinado a atender aos anseios da sociedade. ${ }^{73}$

De outra parte, a ordem jurídica brasileira determina que os partidos políticos devam resguardar a soberania nacional, o regime democrático, o pluripartidarismo e os direitos fundamentais dos seres humanos, assegurando a autenticidade do sistema representativo (art. 17 da Constituição Federal e art. $2^{\circ}$ da Lei $\mathrm{n}^{0}$ 9.096/95).

Desse modo, o sistema representativo baseado no pluripartidarismo implica responsabilidade política do mandatário no exercício da parcela de poder que lhe fora outorgada pela sociedade. Isso significa dizer que poderá o representante eleito, caso exerça o poder de modo abusivo, com violaçāo aos princípios constitucionais democráticos, sofrer sanções políticas, diretamente pelo corpo eleitoral, pela sua não-reeleição, ou mediante açōes especiais previstas no ordenamento jurídico, como a ação eleitoral de impugnação de mandato eletivo (art. 14, $\$ 10$, da Constituição Federal) e a ação civil de improbidade administrativa (Lei no ${ }^{0} 8.429 / 92$ ).

Parece evidente que, tendo o partido político definido previamente e publicamente o programa político que deve ser assumido pelo futuro governo, essas diretrizes de ação tornam-se vinculantes, política e juridicamente, para os futuros representantes eleitos, sob pena de tornar o parlamento e o governo ilegítimo em relação à sociedade.

Dessa forma, é de curial importância que os representantes eleitos se tornem responsáveis pela eventual inadequação e incompatibilidade da atividade parlamentar com os programas de governo.

\footnotetext{
72 ARAS, Augusto. Op. cit., p. 119.

i3 SILVIA, José Afonso da. Curso de direito constitucional positivo. São Paulo: Malheiros, 2007, p. 401.
} 
Para esse fim, o instituto da fidelidade partidária revela-se um importante instrumento de vinculação e controle da atuação individual do parlamentar, na medida em que impede a mudança de partido político e, por conseguinte, de orientaçōes políticas governamentais no curso de uma legislatura.

Cabe ressaltar, por oportuno, que ao adquirir personalidade jurídica após o registro na forma da lei civil (art. $1^{\circ}$, II c/c 114, III da Lei $n^{\circ}$ 6.015/73) e legislação eleitoral (registro do estatuto e do órgão diretivo nacional no Tribunal Superior Eleitoral), o partido político pode funcionar nos moldes de uma associação civil. Por conseguinte, havendo previsão estatutária, os partidos políticos podem desenvolver atividades de controle dos atos do Poder Público (p. ex. proteção ao meio ambiente, ao consumidor, à ordem econômica, à livre concorrência etc.), tornando-se legitimados, inclusive, para a propositura de ação civil pública (art. 5º, I e II, da Lei no 7.347/85).

\subsubsection{O problema da fidelidade partidária}

Apesar da vinculação ao programa de governo parecer uma conseqüência lógica do regime democrático participativo e representar uma condição indispensável de legitimação do poder político, no Brasil raros são os parlamentares e até mesmo os próprios partidos que se mantêm fiéis e coerentes com os seus princípios e programas. O principio da coerência que deve pautar a relação da atividade partidária é policas vezes respeitado. ${ }^{74}$

Após a aprovação da Emenda Constitucional $n^{\circ}$ 25/85, que aboliu a perda do mandato decorrente da infidelidade partidária, instituto inserido na Constituição Federal de 1967, carece o ordenamento jurídico brasileiro de mecanismo de conservação pelo povo das expectativas eleitorais assumidas. A atual Constituição Federal não autoriza a perda do mandato por desrespeito às diretrizes e propostas que serviram de base à escolha do colégio eleitoral, remetendo aos estatutos partidários o estabelecimento de normas de fidelidade e disciplina (art. 17, $\$ 1^{\circ}$ ). Além do mais, o Supremo Tribunal Federal tem iterativa jurisprudência de que a adoção da perda do mandato por infidelidade partidária confrontaria as normas dos artigos 15 e 55 da Constituição Federal.

Argumenta-se ainda, em favor da impossibilidade de perda do mandato político, que o parlamentar tem o direito de oposição democrática, sendo livre para votar de acordo com os ditames de sua própria consciência e em respeito ao seu mandante (eleitor).

Porém, a mudança constante de partidos e a infidelidade aos programas de governo têm revelado na prática parlamentar problemas insuperáveis de gover-

it ARAS, Augusto. Fidelidade partidária: a perda do mandato parlamentar. Rio de Janeiro: Lumen Juris, 2006, p. 176. 
nabilidade. AUGUSTO ARAS ${ }^{75}$ afirma que a migração partidária tem criado, no Congresso Nacional, uma formação política diferente daquela oriunda da manifestação popular materializada nas urnas, introduzindo elemento de instabilidade no interior do Legislativo que obstaculiza a consolidação do sistema representativo partidário, com desgaste da imagem dos partidos e dos políticos com enfraquecimento da democracia participativa.

Prossegue afirmando que:

Tudo isso ocasiona flagrante distorção do sistema representativo, ante a infidelidade dos representantes eleitos que, ex abrupto, desconsideraram a vontade popular que os elegeu em decorrência de compromissos com a bandeira ideológica do partido, alterando, com isso, a soberania popular e a legitimidade do Poder centrada na vontade da maioria dos cidadãos. ${ }^{76}$

Diante desse panorama, busca o referido autor um novo modelo de representação política, que denomina de mandato representativo partidário. Nesse modelo, abre-se espaço para o questionamento da relação entre o partido político e o eleito e a indagação se o titular do mandato ainda seria este ou a agremiação à qual está filiado e sem a qual não poderia participar das eleições.

Em suas palavras:

A representação política deve cada vez mais deixar de ser a representação de uma pessoa eleita pelo cidadão para se firmar como a representação de uma ideologia professada por parcela da sociedade institucionalizada na constituição formal de um grupo político dotado de capacidade eleitoral, passando a ser uma representação partidária. ${ }^{77}$

MARCOS RAMAYANA ${ }^{78}$ pondera que: "o partido político que perde um parlamentar eleito pela sua legenda, na verdade, torna-se enfraquecido em termos de bancada e representatividade, além de ser atingido na vaga do quociente eleitoral (arts. 107 e 109, $\$ 1^{\circ}$, do Código Eleitoral)".

FERNANDO BARBALHO MARTINS revela-se mais contundente nas críticas à impossibilidade de perda do mandato político por infidelidade partidária:

Diante da situação que exige do candidato a necessária filiação a um partido político, implicando tal requisito na assunção, por parte do mesmo candidato, dos deveres e condições estabelecidas pela agremiação que o acolhe em seus quadros, assim como na prévia aprovação por uma convenção partidária, de sua inclusão na legenda que concorrerá em determinado

\footnotetext{
75 Op. cit., p. 249.

76 Op. cit., p. 250.

i- Op. cit., p. 291-292.

78 Direito eleitoral. Niterói: Impetus, 2007, p. 254.
} 
pleito, a pura e simples troca de filiação após obtido o mandato contraria qualquer expectativa traçada pelo critério do chamado "homem médio". Tal situação se agrava ainda mais quando se lembra que os votos que conduziram o candidato ao assento no Parlamento via de regra sāo amealhados entre seus correligionários, aproveitando-se aquele da estrutura legal, e, por vezes, material e pessoal, do partido cujos quadros o voto judicial criticado não vê nenhum problema em abandonar. ${ }^{79}$

Sugere o autor que, em tais situações, pode o parlamentar responder por quebra de decoro parlamentar, única via possível de perda do mandato, mas de nenhuma inutilidade prática por conta das conveniências políticas do Parlamento:

A violação de tais deveres fundamentais pode ser facilmente enquadrável no abuso das prerrogativas outorgadas aos parlamentares, autorizando a incursão do político "itinerante" na prática de quebra de decoro e, por conseguinte, na perda de seu mandato. É evidente que a classe política que atualmente ocupa grande parte do plenário das casas legislativas ao redor do país não levaria a cabo esta interpretação ousada dos dispositivos normativos que regem a espécie, mas parece ser esta a única compatível com a efetividade dos mandamentos constitucionais que consagram a figura dos partidos políticos, até mesmo de forma a evitar mais uma escusa formal do Ministro Sepúlveda Pertence, formulada no voto ora debatido e que reproduziria em julgamentos no TSE.

Apesar de a jurisprudência do Supremo Tribunal Federal ser contrária à perda do mandato, recente decisão plenária do Tribunal Superior Eleitoral, respondendo à Consulta $\mathrm{n}^{\mathrm{o}} 1398$ do Partido da Frente Liberal, atualmente Democratas, decidiu, por maioria, que os mandatos conquistados pelos deputados federais da eleição de 2006, assim como todos os eleitos pelo sistema de representação proporcional, no fundo, pertencem aos respectivos partidos políticos, e não aos parlamentares. Os argumentos sustentados relembram que a filiação partidária é uma condição de elegibilidade constitucional e que os partidos podem estabelecer normas de fidelidade partidária, além de regras de disciplina. ${ }^{80}$

Inobstante pairarem dúvidas quanto ao alcance da aplicação e execução dessa decisão do Tribunal Superior Eleitoral, sua edição fez apressar a votação da reforma política do país, que se encontra em tramitação e discussão no Congresso Nacional. A essência da reforma está contida nos Projetos de Lei nos 2.679/03 e $1.712 / 03 .{ }^{81}$ Entre as mudanças propostas estāo o financiamento público das campa-

\footnotetext{
79 Do direito à democracia: neoconstitucionalismo, princípio democrático e a crise no sistema representativo. Rio de Janeiro: Lumen Juris, 2007, p. 198.

80 RAMAYANA, Marcos. Direito eleitoral. Niterói: Impetus, 2007, p. 254-255.

81 Agência Câmara: <http://www.camara.gov.br>.
} 
nhas, ${ }^{82}$ o voto de legenda por meio das listas preordenadas de candidatos, ${ }^{83}$ a criação de federaçōes partidárias ${ }^{84}$ e a redução da cláusula de barreira dos partidos políticos. ${ }^{85}$

\subsubsection{Os vícios de representação político-partidária no direito brasileiro}

Não apenas a falta de regras e o apego positivista da jurisprudência do Supremo Tribunal Federal para a perda do mandato parlamentar por infidelidade partidária, que contribui em última análise para o desrespeito aos programas de governo do partido, têm ocasionado um déficit de representatividade popular legítima na instituição e promoção de políticas públicas.

O próprio funcionamento do Congresso Nacional e os vícios de representação político-partidária agravam o quadro, proporcionando ao Chefe do Poder Executivo manobrar um amplo e irrestrito poder sobre a agenda governamental do país.

Como se sabe, a Constituição Federal de 1988, diferentemente das anteriores, atribuiu uma extensa gama de poderes ao Executivo para a iniciativa do estabelecimento de políticas públicas. O Presidente da República tem exclusividade de iniciativa no processo legislativo em matéria administrativa, orçamentária e fiscal,

82 Conforme a proposta serāo incluídos na Lei Orçamentária créditos adicionais para financiar campanhas eleitorais com valores equivalentes ao número de eleitores do país. Os recursos serão multiplicados por $R \$ 7$, tomando-se por referência o eleitorado existente em 31 de dezembro do ano anterior à elaboração da Lei Orçamentária. O Tesouro Nacional depositará os recursos no Banco do Brasil em conta especial à disposiçāo do Tribunal Superior Eleitoral, cabendo a este Tribunal fazer a distribuição dos recursos aos diretórios nacionais dos partidos políticos obedecendo os seguintes critérios: 1\%, dividido igualitariamente entre todos os partidos com estatutos aprovados pelo Tribunal Superior Eleitoral; $14 \%$ divididos igualitariamente entre os partidos e federaçōes com representaçāo na Câmara dos Deputados; e $85 \%$ divididos entre os partidos e federaçōes, proporcionalmente ao número de representantes que elegeram na última eleição geral para a Câmara dos Deputados.

83 Conforme a proposta os eleitores não mais elegerão individualmente seus candidatos a vereador, deputado estadual e federal, mas votarāo em listas previamente ordenadas pelos partidos. A distribuição de cadeiras seria semelhante à que se processa hoje: cada partido continuaria recebendo o número de lugares que the corresponde pela proporção de votos que obteve. Assim, se um partido tem direito a oito cadeiras, entram os oito primeiros colocados na lista.

${ }_{84}$ Sistema proposto para substituir as coligações partidárias nas eleições proporcionais (para vereador, deputado estadual e deputado federal). A federação permite que os partidos com maior afinidade ideológica e programática se unam para atuar de maneira uniforme em todo o país e, ao mesmo tempo, contribui para que os pequenos partidos ultrapassem a clausula de barreira. Durante três anos, eles deixarão de atuar como partidos isolados e passarão a agir como se fossem um único partido. Hoje um partido pode se coligar com outro para uma eleição e desfazer a união logo em seguida. As coligaçōes nas eleiçōes majoritárias (para prefeito, governador, senador e presidente da Republica) continuarão a valer.

${ }^{85}$ Prevista na Lei dos Partidos Políticos (Lei $n^{0}$ 9.096/95), esse dispositivo determina que tem direito a funcionamento parlamentar, em todas as Casas Legislativas para as quais tenha eleito representante, o partido que, na eleiçāo para Câmara dos Deputados, obtenha no mínimo $5 \%$ dos votos apurados, distribuídos em pelo menos $1 / 3$ dos Estados, com um mínimo de $2 \%$ do total de cada um deles. $\mathrm{O}$ projeto prevê a redução do percentual para $2 \%$ dos votos apurados nacionalmente, nāo computados os brancos e nulos, distribuídos em pelo menos nove Estados. O partido precisa também eleger, no mínimo, um representante em cinco Estados. 
podendo pedir urgência para as leis que apresenta, possuindo ainda autoridade delegada de decretos e a edição de medidas provisórias com força de lei.

De outro lado, o Congresso brasileiro possui uma estrutura institucional de atuação que afeta o seu poder como órgão autônomo e independente de elaboração e controle das políticas públicas e do Poder Executivo, na medida em que confere amplos poderes aos líderes partidários sobre o processo legislativo, afastando a atuação individual dos parlamentares.

Em tais condições, como bem referido por ARGELINA CHEIBUB FIGUEIREDO, aumenta o sucesso do Presidente em aprovar suas propostas legislativas e seu predomínio na formulação de políticas públicas, ao mesmo tempo em que enfraquece o papel do Congresso como Poder apto a fiscalizar o Executivo.

Essas regras constitucionais e regulamentos legislativos dão ao Executivo e aos líderes da coalizão governista meios para promover a cooperação no Legislativo, alem de neutralizarem o comportamento individualista dos legisladores. Em um sistema partidário fragmentado, os membros do Congresso podem ter incentivos eleitorais para perseguir objetivos particulares, mas falta-lhes capacidade para consegui-los. Os esquemas institucionais conspiram contra o seu sucesso, seja em matéria de legislação, seja de fiscalização. ${ }^{86}$

Assim, em modelos institucionais como este, a eficácia do controle do Congresso passa a depender muito de fatores externos, como a mobilização da opinião pública pela imprensa e por grupos organizados, conforme se tem evidenciado nos últimos anos.

Além desse fator institucional de organização dos Poderes Estatais, as deturpações do sistema representativo brasileiro, caracterizado, dentre outros fatores, pelas reiteradas notícias de corrup̧̧ão, têm levado parte do eleitorado brasileiro a prestigiar a pessoa do candidato em detrimento do partido político que integra. Isso acarreta a adesão do eleitorado a propostas, programas e projetos partidários incompatíveis com as suas reais intençōes, desvirtuando o mérito do sufrágio.

Segundo AUGUSTO ARAS, ${ }^{87} \mathrm{o}$ "engajamento do brasileiro nas atividades partidárias é 'mercenário', isto é, ocorre apenas mediante remuneração, nos períodos eleitorais. Há pouco engajamento ideológico nestas atividades". Tudo isto, segundo o mesmo autor, aponta para um distanciamento dos brasileiros da esfera político-partidária, estando a maioria das agremiações ainda sujeitas ao caciquismo, ao coronelismo, vale dizer, algumas personalidades célebres é que comandam estas instituições, segundo os seus interesses político-eleitorais.

86 Instituiçōes e política no controle do executivo. Revista de Ciências Sociais, Rio de Janeiro, v. 44, n" 4, 2001, p. 694.

8. Fidelidade partidária: a perda do mandato parlamentar. Rio de Janeiro: Lumen Juris, 2006, p. 175. 
FERNANDO BARBALHO MARTINS ${ }^{88}$ refere ainda como vício congênito do sistema federativo de representação, passível de declaração de inconstitucionalidade, a grave distorção na proporcionalidade dos representantes estaduais na Câmara dos Deputados, em decorrência das disposições do art. $45, \$ 1^{\circ}$, da Constituição Federal. ${ }^{89}$ Cita o autor que a origem do problema reside no famigerado Pacote de Abril apresentado em 1977 pelo governo militar a fim de estancar o movimento oposicionista que ganhava vulto no país, garantindo maior peso aos Estados do Norte-Nordeste e Centro-Oeste, à época com eleitorados mais alinhados com o regime militar.

O sistema proporcional pode conferir a um partido político sem estrutura e sem expressão, apoiado em apenas um nome, representação no Legislativo, que não corresponde ao equilíbrio desejado e que não se legitima por esta distorção. Ocorre com freqüência nas eleições candidatos com grande votação individual, não eleitos, perdendo sua vaga para candidatos com votaçōes inexpressivas, eleitos com a votação de seu colega de partido, com uma votação muito grande. ${ }^{90}$

Vaticina ROBERTO AMARAL que esses vícios caracterizam fraude contra o eleitorado:

Votando no candidato de sua preferência, o eleitor pode estar elegendo outro, dele desconhecido, e de outro partido, porque seu voto, em face do sistema de sobras, pode ser transferido para outro partido. Votando em um partido, pode estar elegendo candidato de outro partido, hipótese de coligaçōes proporcionais. Votando na Oposiçāo, pode estar elegendo um situacionista. Votando na legenda de um partido, com a evidente intenção de reforçá-la, o eleitor pode estar elegendo candidato de outra legenda, elegendo candidato de partido que sequer atingiu o quociente eleitoral. Finalmente: o eleitor vota num candidato e pode estar elegendo outro. ${ }^{91}$

Não há dúvida de que esses vícios de representaçāo enfraquecem sobremaneira o Poder Legislativo no controle das políticas públicas propostas e encaminha-

\footnotetext{
88 Do direito à democracia: neoconstitucionalismo, princípio democrático e a crise no sistema representativo. Rio de Janeiro: Lumen Juris, 2007, p. 89-131.

89 “Art. 45. A Câmara dos Deputados compōe-se de representantes do povo, eleitos, pelo sistema proporcional, em cada Estado, em cada Território e no Distrito Federal.

$\$ 1^{\circ}$ O número total de Deputados, bem como a representação por Estado e pelo Distrito Federal, será estabelecido por lei complementar, proporcionalmente à populaçăo, procedendo-se aos ajustes necessários, no ano anterior às eleiçōes, para que nenhuma daquelas unidades da Federação tenha menos de oito ou mais de setenta Deputados."

90 Refere CÍNTHIA ROBERT e JOSÉ LUIZ QUADROS DE MAGALHÃES que o sistema proporcional, teoricamente, vincula o nome e a sigla e deveria levar o eleitor a observar tanto a proposta e o programa partidário, como a pessoa do partido que ele acredita ser capaz de realizar, com competência, este programa e sua representação política. Teoria do estado e poder local. Rio de Janeiro: Lumen Juris, 2002, p. 186.

91 A democracia representativa está morta: viva a democracia participativa! In GRAU, Eros Roberto e GUERRA FILHO, Willis Santiago (Org.). Direito constitucional: estudos em homenagem a Paulo Bonavides. Sāo Paulo: Malheiros, 2003, p. 27.
} 
das pelo Poder Executivo. Resta, dessa forma, no esquema de freios e contrapesos dos Poderes do Estado, a atuação do Judiciário, que em matéria de controle das políticas públicas tem evoluído sua jurisprudência, ainda que com forte resistência doutrinária.

\subsection{Controle judicial}

O controle jurisdicional da Administração Pública abrange a fiscalização e a correção dos atos ilegais e, em determinadas circunstâncias, o controle de mérito praticado pelos órgãos do Executivo e dos demais poderes que exercem funções administrativas. ${ }^{92}$ Essa via de controle dos atos da Administração Pública é considerado elemento essencial à democracia, princípio estruturante do Estado de Direito, como garantidor das liberdades democráticas.

Nesse sentido, LÚCIA VALLE DO FIGUEIREDO assevera:

Verificamos, assim, que o controle jurisdicional é princípio estruturante do Estado de Direito. A possibilidade de controle jurisdicional, como hoje se conhece, como influência da Constituição Americana, sobretudo de Marshall, do judicial review, aparece na Constituição da República, 1891, e sobrevive até agora. A possibilidade de controle judicial é a mola propulsora do Estado de Direito. ${ }^{93}$

O sistema jurisdicional brasileiro adota, para fins de controle judicial da Administração, a jurisdição una (art. 5ª, XXXV, da Constituição Federal). Esse sistema consagra o monopólio jurisdicional ao Poder Judiciário, ao contrário de alguns países europeus, como França e Portugal, em que se adota o sistema do contencioso administrativo, pelo qual a Administração resolve seus conflitos com os particulares por intermédio de órgãos administrativos especialmente qualificados para essa tarefa.

Dessa forma, o controle jurisdicional da Administração Pública está aberto ao Poder Judiciário sempre que qualquer ação ou medida de autoridade administrativa, eivada de ilegalidade ou abuso de poder, traga ou ameace trazer prejuízos

\footnotetext{
92 No entender de JUAREZ FREITAS, o controle do ato administrativo deve ser mais amplo, guardando vinculação inteira com o sistema positivado: "O controle realizado pelo Poder Legislativo e Judiciário, em especial por este último, no sistema de jurisdição única, há de ser preponderantemente principiológico, sobrepassando, neste aspecto e mais uma vez, as antigas classificaçōes rígidas dos atos administrativos, enfatizada a inexistência de atos exclusivamente políticos: tanto os atos administrativos vinculados quanto os discricionários devem guardar vinculaçāo inteira com o sistema positivado. O mérito do ato nāo há de ser inquirido, mas, até em razão disso, o controle de sua adequação deve ser realizado com maior rigor, uma vez que a discrição existe, presumidamente, para que o agente concretize, com maior presteza, a vinculante finalidade do sistema." Estudos de direito administrativo. São Paulo: Malheiros, 1995, p. 146.

93 O controle jurisdicional da administração pública. Revista Diálogo Jurídico, Salvador, v. I, nº 2, maio 2001 , p. 2.
} 
ao administrado, mormente num Estado de Direito firmado no princípio da legalidade. ${ }^{94}$

Nas palavras de CELSO ANTÔNIO BANDEIRA DE MELLO:

Se a legalidade tem caráter protetor dos indivíduos, resulta que estes têm direito a ela e pessoal interesse em sua restauração quando a quebra da ordem jurídica implicar agravo ou subtração de vantagem que os atinja individualmente, pouco importando se a ilegalidade argüida alcança especificamente um ou um conjunto de indivíduos concorrentemente afetados, por estarem ubicados na mesma situação objetiva e abstrata. ${ }^{95}$

Porém, esse controle judicial dos atos da administração não é ilimitado. Como bem assinala DIOGO DE FIGUEIREDO MOREIRA NETO, ${ }^{96}$ o controle exercido pelo Poder Judiciário sofre restrições quanto à matéria (crimes de responsabilidade), quanto à amplitude do ato de controle (mérito), quanto à oportunidade do pronunciamento (ato incompleto) e quanto à extensão do pronunciamento (coisa julgada).

No tocante ao controle de mérito dos atos discricionários, que possui relação direta com as políticas públicas, via de regra, estes atos não estão sujeitos à apreciaçāo do Poder Judiciário, que só verifica e julga a regularidade dos elementos vinculados do ato.

\section{Segundo MARIA SYLVIA ZANELLA DI PIETRO:}

Isso ocorre precisamente pelo fato de ser a discricionariedade um poder delimitado previamente pelo legislador. Este, ao definir determinados atos, intencionalmente deixa um espaço para livre decisão da Administração Pública, legitimando previamente sua opção; qualquer delas será legal. Daí por que não pode o Judiciário invadir esse espaço reservado, pela lei, ao administrador, pois, caso contrário, estaria substituindo por seus próprios critérios de escolha a opção legítima feita pela autoridade competente com base em razões de oportunidade e conveniência que ela, melhor do que ninguém, pode apreciar diante de cada caso concreto. ${ }^{97}$

\footnotetext{
94 Sobre esse tema consulte-se, por todos, FREITAS, Juarez. Atos administrativos: a indispensável distinção entre anulação e decretação de nulidade absoluta. Boletim de Direito Administrativo 35:724728, out. 2000; VITTA, Heraldo Garcia. Invalidação dos atos administrativos. Revista de Direito Administrativo 220:35-51, abr./jun. 2000; FRANÇA, Vladimir da Rocha. Classificação dos atos administrativos inválidos no direito administrativo brasileiro. Revista de Direito Administrativo 226:59-80, out./dez. 2001.

95 MELLO, Celso Antônio Bandeira de. Controle judicial dos atos administrativos. Revista de Direito Público, 65:27-38, 1983.

96 Curso de direito administrativo. Rio de Janeiro: Forense, 2001, p. 226.

97 Discricionariedade administrativa na constituição de 1988. São Paulo: Atlas, 2001, p. 133. Vale referir a atual posiçāo do direito alemāo a propósito da discricionariedade no que concerne ao controle judicial. HARTMUT MAURER afirma que: "O significado do poder discricionário consiste em que todas as medidas que a autoridade toma no quadro de seu poder discricionário são conforme o direito e,
} 
Dentre os órgãos integrantes do Poder Judiciário (art. 92 da Constituição Federal), ${ }^{98}$ apenas os Tribunais e Juízes Militares não possuem competência para controle de políticas públicas, uma vez que compete à Justiça Militar processar e julgar os crimes militares definidos em lei (art. 124 da Constituição Federal).

No entanto, o controle de legitimidade das escolhas discricionárias do Poder Público, e por via indireta das políticas públicas, tem encontrado no contexto do Estado Democrático de Direito um rápido desenvolvimento, sendo necessário referir que diferentes e contundentes críticas são dirigidas à idéia de um controle jurídico das políticas governamentais do Estado, como adiante se verificará.

\subsection{O papel limitado da Justiça Eleitoral}

O processo eleitoral ${ }^{99}$ brasileiro encontra-se sob o controle exclusivo do Poder Judiciário (art. 118 ss. da Constituição Federal), com a fiscalização do Ministério Público Eleitoral (art. 127 da Constituição Federal) e regido por normas de direito público, denominado direito eleitoral. ${ }^{100}$

Segundo MARCOS RAMAYANA, direito eleitoral é o ramo do direito público que:

disciplina o alistamento eleitoral, o registro de candidatos, a propaganda política eleitoral, a votação, apuração e diplomação, além de regularizar os sistemas eleitorais, os direitos políticos ativos e passivos, a organização judiciária eleitoral, dos partidos políticos e do Ministério Público dispondo de um sistema repressivo penal especial. ${ }^{101}$

Entretanto, a competência da Justiça Eleitoral encerra-se na fase da diplomação dos candidatos ${ }^{102}$ e prolonga-se, excepciona!mente, no exame das açōes propostas

assim, no caso de um exame judicial-administrativo devem ser aprovadas. Se as medidas respectivas são conforme a finalidade, convenientes e razoáveis é insignificante na perspectiva jurídica. A decisāo sobre isso está exclusivamente no âmbito de responsabilidade da administraçāo." Elementos de direito administrativo alemão. Porto Alegre: Sérgio Fabris, 2000, p. 49.

98 "Art. 92. São órgãos do Poder Judiciário: I - o Supremo Tribunal Federal; I-A - o Conselho Nacional de Justiça; II - o Superior Tribunal de Justiça; III - os Tribunais Regionais Federais e Juízes Federais; IV - os Tribunais e Juizes do Trabalho; V - os Tribunais e Juízes Eleitorais; VI - os Tribunais e Juízes Militares; VII - os Tribunais e Juízes dos Estados e do Distrito Federal e Territórios."

99 Sāo fases do processo eleitorai: alistamento, convençōes nacionais, estaduais e municipais para escolha de pré-candidatos, pedido de registro de candidaturas, propaganda política eleitoral, votação, apuração, proclamação dos eleitos e diplomação.

100 As principais leis eleitorais são: Lei $n^{\circ} 4.737 / 65$, que institui o Código Eleitoral; Lei Complemen$\operatorname{tar} n^{\circ} 64 / 90$, que estabelece casos de inelegibilidade; Lei $n^{\circ} 9.096 / 95$, que dispõe sobre os partidos políticos; Lei $n^{\circ} 9.504 / 97$, que estabelece normas para as eleiçōes; Lei $n^{\circ} 6.091 / 74$, que dispōe sobre o fornecimento de transporte gratuito em dias de eleição; Lei $n^{0} 6.996 / 82$, que dispōe sobre o processamento eletrônico de dados nos serviços eleitorais; e a Lei $n^{0} 7.444 / 85$, que dispōe sobre a implantação do processamento eletrônico de dados no alistamento eleitoral.

101 Direito eleitoral. Niterói: Impetus, 2007, p. 25.

102 Cabe esclarecer que o ato de diplomação equivale ao da nomeação do servidor público. 
durante a fase do processo de propaganda política eleitoral e votação, bem como em relação à ação de impugnação de mandato eletivo no prazo de 15 dias da diplomação (art. 14, $\$ \$ 10$ e 11 , da Constituição Federal) ${ }^{103}$ e no julgamento do recurso contra a diplomação no prazo de três dias (art. 262, I a IV, do Código Eleitoral).

Em razão desses exíguos prazos de preclusão das referidas açōes, bem como da limitação material a que está subordinada, o controle das políticas públicas pela Justiça Eleitoral revela-se mais de caráter preventivo e indireto do que propriamente de mérito ou repressivo.

Nesse contexto, o papel da Justiça Eleitoral passa a ser o de evitar a diplomação de candidaturas que, de modo direito ou indireto, violem as leis eleitorais e os princípios constitucionais do sufrágio universal e da democracia representativa.

Portanto, a possibilidade de controle judicial de políticas públicas pela Justiça Eleitoral é bastante limitada, e somente por via transversa, ou seja, no exercício do controle externo dos partidos políticos e do processo eleitoral, pode ser alcançado algum resultado prático.

\subsubsection{As teses doutrinárias}

Sob o enfoque do controle de legalidade e constitucionalidade das políticas públicas pelos demais órgãos do Poder Judiciário, não há limitação material de competência, uma vez que o ordenamento jurídico brasileiro adota o princípio da inafastabilidade da jurisdição.

O debate, todavia, relaciona-se com a possibilidade de controle das escolhas em matéria de gastos públicos, tanto em termos de limitação ou acréscimo, quanto de substituição dos meios empregados e dos fins visados.

ANA PAULA DE BARCELLOS sistematiza algumas das críticas contrárias ao controle jurídico e jurisdicional das políticas públicas, agrupando-as em três tipos de argumentação distintos: o primeiro grupo congrega argumentos em geral associados ao debate sobre a teoria da Constituição, seu papel e alcance. $O$ segundo procura veicular óbices de natureza predominantemente filosófica, ao passo que o terceiro grupo reúne críticas que podem ser descritas como operacionais. ${ }^{104}$

O primeiro grupo de críticas argumenta que o quanto se deve gastar de recursos públicos, com que finalidade, em que e como são decisōes próprias da esfera de deliberação política democrática e majoritária, e não do magistrado.

\footnotetext{
103 Até a presente data, o preceito constitucional ainda nāo foi regulamentado. Encontra-se em tramitação no Senado Federal o Projeto de Lei n 3.781/97 (PLS n² 88/97), de autoria do Senador Antônio Carlos Magalhães, que visa regulamentar a referida açāo de impugnação.

104 Constitucionalização das políticas públicas em matéria de direitos fundamentais: o controle político-social e o controle jurídico no espaço democrático. Revista de Direito do Estado, ano 1, $\mathbf{n}^{2} 3$, jul./set. 2006, p. 24-25.
} 
O segundo grupo de críticas argumenta que seria presunçoso e paternalista afirmar que os juizes tomariam melhores decisões em matéria de políticas públicas que os agentes públicos encarregados dessa função.

A terceira crítica argumenta que, superados os argumentos anteriores, o fato é que nem o jurista, e muito menos o juiz, dispõem de elementos ou condições de avaliar, sobretudo em demandas individuais, a realidade da ação estatal como um todo. Em outras palavras, preocupado com a solução dos casos concretos (microjustiça), o juiz fatalmente ignora outras necessidades relevantes e a necessidade inexorável de gerenciar recursos limitados para o atendimento de demandas ilimitadas (macrojustiça), ou seja, sem desencadear amplas distorções no sistema de políticas públicas globalmente consideradas. ${ }^{105}$

Na opinião de ANA PAULA DE BARCELLOS, as duas primeiras críticas têm sua importância relativizada na medida em que: (i) a discussão envolva direitos que constituem pressupostos para o funcionamento da deliberação majoritária e sem os quais o controle social das políticas públicas dissipa-se no ciclo corrupção-ineficiência-clientelismo; e (ii) o controle jurisdicional das políticas públicas tenha por fundamento elementos normativos específicos, padrões ou consensos morais ou conhecimentos técnicos-científicos consolidados. A terceira crítica é a mais complexa, mas pode ser neutralizada em boa medida a partir de diferentes objetos e modalidades de controle.

Assim, propõe a referida autora, considerando as políticas públicas promotoras de direitos fundamentais, cinco objetos que podem sofrer controle jurídico e jurisdicional. São eles: (i) fixação de metas e prioridades por parte do Poder Público em matéria de direitos fundamentais; (ii) o resultado final esperado das políticas públicas; (iii) a quantidade de recursos a ser investida em políticas públicas vinculadas à realização de direitos fundamentais, em termos absolutos ou relativos; (iv) o atingimento ou não das metas fixadas pelo próprio Poder Público; e (v) a eficiência mínima (entendida como economicidade) na aplicação dos recursos públicos destinados a determinada finalidade.

Os dois primeiros objetos de controle se ocupam do conteúdo das políticas públicas em si, ao passo que os três últimos pretendem controlar aspectos do processo de decisão e execução das políticas públicas levado a cabo pelo Poder Público. ${ }^{106}$

Ainda que não trate especificamente do controle judicial das políticas públicas, mas na mesma linha do entendimento acima referido, GUSTAVO BINENBO$\mathrm{JM}^{107}$ propõe uma teoria da vinculação direta dos atos administrativos discricionários aos princípios fundamentais. Sua teoria baseia-se no fato de que, estando

\footnotetext{
105 Op. cit., p. 25-34.

106 Op. cit., p. 54.

107 Uma teoria do direito administrativo: direitos fundamentais, democracia e constitucionalizaçāo. Rio de Janeiro: Renovar, 2006, p. 205-238.
} 
superada a concepção positivista de que a lei contém todo o direito, passa-se a fundamentar a atividade administrativa na vinculaçāo à ordem jurídica como um todo (princípio da juridicidade) ${ }^{108} \mathrm{~A}$ assunção desse princípio não mais permite falar em uma dicotomia de ato vinculado-ato discricionário, mas sim de diferentes graus de vinculação dos atos administrativos à juridicidade. Ao maior ou menor grau de vinculação à juridicidade corresponderá maior ou menor grau de controlabilidade judicial dos atos administrativos.

Segundo o autor, passa-se então a uma escala crescente de densidade normativa vinculativa: (i) atos vinculados por regras (constitucionais, legais ou regulamentares); (ii) atos vinculados por conceitos jurídicos indeterminados (constitucionais, legais ou regulamentares); (iii) atos vinculados diretamente por princípios.

Assim, o resultado do estreitamento do mérito do ato administrativo poderá ser: (i) redução das possíveis opçōes à escolha do administrador, dentro do quadro de juridicidade; (ii) redução da discricionariedade a zero, quando restar apenas uma escolha conforme a juridicidade.

Em outra linha de entendimento, FÁBIO KONDER COMPARATO ${ }^{109}$ procura argumentar sobre o controle das políticas públicas restringindo-se ao exame de constitucionalidade das leis.

Inicialmente esclarece que se deve afastar a clássica objeção de que o Judiciário não tem competência, pelo princípio da divisão de Poderes, para julgar "questōes políticas". Mesmo sob a égide da Constituição de 1934, que vedava ao Poder Judiciário conhecer de questões exclusivamente políticas (art. 68), a hermenêutica prevalecente era a de que não se devia confundir competência ratione materiae com competência ratione numeris. A declaração de guerra e a licença para que seja processado judicialmente um deputado constituem matéria que refogem inteiramente à competência funcional do Judiciário. Mas nenhum deles fica imune ao juizo de compatibilidade com as regras especificamente postas pela Constituição para a sua prática. ${ }^{110}$

Em segundo lugar, observa que as políticas públicas, enquanto conjunto de normas e atos, tomadas isoladamente, são de natureza heterogênea e submetemse a um regime jurídico que lhes é próprio. De onde se segue que o juízo de validade de uma política - seja ela empresarial ou governamental - não se confunde nunca com o juízo de validade das normas e dos atos que a compõem. Uma lei, editada no quadro de determinada política pública, por exemplo, pode ser inconstitucional, sem que esta última o seja. Inversamente, determinada política governamental, em razão de sua finalidade, pode ser julgada incompatível com os

I08 Consulte-se, por todos, OTERO, Paulo. Legalidade e administração pública: o sentido da vinculaçāo administrativa à juridicidade. Coimbra: Almedina, 2003.

109 Ensaio sobre o juízo de constitucionalidade de políticas públicas. Revista de Informaf̧ão Legislativa, Brasília, ano 35, nº 138, abr./jun. 1998.

110 Op. cit., p. 46. 
objetivos constitucionais que vinculam a ação do Estado, sem que nenhum dos atos administrativos praticados, ou nenhuma das normas que a regem, sejam, em si mesmos, inconstitucionais. ${ }^{111}$

Esclarecidas essas situações, FÁBIO KONDER COMPARATO argumenta que o juízo de constitucionalidade nessa matéria tem por objeto não só as finalidades, expressas ou implícitas, de uma política pública, mas também os meios empregados para se atingirem esses fins. Exemplifica essa hipótese com uma política de estabilidade monetária fundada na prática de juros bancários extorsivos e na sobrevalorização do câmbio, ou uma política de indiscriminada concessão de incentivos fiscais a qualquer exploração agrícola. Afirma ainda que a política governamental pode violar a Constituição em razão da própria maneira como é estruturada. $O$ exemplo seria uma política estadual ou municipal de saúde pública desligada do sistema nacional único. ${ }^{112}$

Por outro lado, reconhece o autor que em matéria de políticas públicas pode haver inconstitucionalidade por omissão. Por exemplo, o art. $182, \mathbb{1} 1^{\circ}$, da Constituição impõe a todos os Municípios com mais de vinte mil habitantes a elaboração de um plano-diretor como instrumento básico da política de desenvolvimento e de expansão urbana.

No entanto, quanto aos efeitos de uma declaração de inconstitucionalidade de políticas públicas, reconhece que há de produzir-se tão-só com efeitos ex nunc, ou seja, com a preservação de todos os atos ou contratos concluídos antes do trânsito em julgado da decisão, sob pena de se instaurar o caos na Administração Pública e nos negócios privados. Além do mais, afirma que seria conveniente que fosse reconhecido ao Poder Judiciário competência preventiva para impedir a realização de uma política pública inconstitucional.

Ainda que viável em tese o controle de constitucionalidade de políticas públicas, entende o autor que haveria necessidade de reformas constitucionais que visem adequar o controle à estrutura tradicional da Constituição brasileira, especialmente quanto à forma processual da demanda, legitimidade das partes e competência judiciária.

Em sua opinião, a ação deveria ser exclusivamente direta e não incidental. Isto porque uma política pública é sempre decidida e executada no nível mais elevado da instância governamental e é muito comum o seu espraiamento por toda a Administração Pública e o concurso legislativo para a consecução de seus objetivos.

Nessas condiçōes, não faz sentido que o litígio a respeito da constitucionalidade possa ser decidido incidentalmente, no curso de outro processo judicial, tendente à solução de uma lide particular. Por via lógica de conseqüência, o órgão judiciário competente haveria de ser, com exclusividade, aquele colocado na cúpula do sis-

\footnotetext{
111 Op. cit., p. 45.

1.12 Op. cit., p. 46
} 
tema, em cada nivel de estrutura federativa. Quanto à legitimidade para propor a ação, ela deveria ser a mais ampla possível, alcançando inclusive quaisquer organizações não governamentais. Parte legítima passiva na relação processual seria, naturalmente, o Chefe do Poder Executivo. ${ }^{113}$

Mesmo que relevantes os entendimentos doutrinários acima referidos, a questão do controle judicial das políticas e dos gastos públicos do Estado não deixa de ser reduzido, em última análise, ao controle dos fins constitucionais e legais (finalidade pública) que devem ser buscados pelo Poder Público, tendo como parâmetros a legalidade e a legitimidade. Essa técnica de controle possui a vantagem de neutralizar as críticas de que o Poder Judiciário não poderia controlar o mérito do ato administrativo, ou seja, as escolhas convenientes e oportunas do Poder Executivo, já que o faz de modo indireto pela análise da finalidade da lei ou do ato.

Para DIOGO DE FIGUEIREDO MOREIRA NETO, sendo certo que a vinculação legal do ato administrativo ao interesse público envolve três dos seus tradicionais elementos (finalidade, motivo e objeto), a legitimidade de um ato administrativo será definida pelos fins. E, desde que tais fins estejam expressa ou implicitamente contidos na lei, torna-se possível traduzi-la em termos de legalidade e, assim, indiretamente, submetê-la a controle.

Em outros termos:

aquilo que o Judiciário pode controlar no ato discricionário não é, diretamente, a sua legitimidade, ou seja, não é o mérito do ato que a expressa, mas a sua legalidade, à qual estarão sempre vinculados todos os atos da Administração, expressada na finalidade. ${ }^{114}$

Assim, o controle de finalidade se concentra em precisar os limites do poder discricionário, além dos quais não há uso correto da discricionariedade, mas seu abuso. ${ }^{115}$ Não se trata, portanto, de determinar qual a atuação ótima ou mais correta para atender ao interesse público, mas de identificar as que o desatendem por extravasar dos limites legais do seu exercício. ${ }^{116}$

\footnotetext{
113 Op. cit., p. 47.

114 Legitimidade e discricionariedade. Rio de Janeiro: Forense, 1998, p. 28.

115 Para DIOGO DE FIGUEIREDO MOREIRA NETO, discricionariedade "é a qualidade da competência cometida por lei à Administraçāo Pública para definir, abstrata ou concretamente, o resíduo de legitimidade necessário para integrar a definição de elementos essenciais à prática de ato de execução voltados ao atendimento de um interesse público específico". Op. cit., p. 32-33.

116 Nesse ponto, DIOGO DE FIGUEIREDO se contrapōe a CELSO ANTÔNIO BANDEIRA DE MELLO, para quem o "dever jurídico que se póe para a Administração é necessariamente o de escolher a melhor solução - não qualquer solução comportada, in abstrato, pelo âmbito de liberdade que lhe deferiu a norma legal. Em outras palavras, existe para a Administração um 'dever jurídico de boa administraçāo'. Não se trata apenas de um dever ético, ou de um dever político, ou de um dever de Ciência da Administraçāo". Controle judicial dos atos administrativos. Revista de Direito Público, 65, 1983, p. 33.
} 
E esses limites segundo DIOGO DE FIGUEIREDO MOREIRA NETO são os princípios da realidade e da razoabilidade. ${ }^{117} \mathrm{O}$ primeiro parte da consideração de que o direito volta-se à disciplina da convivência real entre os homens e todos os seus atos partem do pressuposto de que os fatos que sustentam suas normas e demarcam seus objetivos são verdadeiros.

Com efeito:

um ato do Poder Público que esteja lastreado no inexistente, no falso, no equivocado, no impreciso e no duvidoso não está, por certo, seguramente voltado à satisfação de um interesse público; da mesma forma, o ato do Poder Público que se destine à realização de um resultado fático inalcançável não visa a satisfazer a um interesse público. ${ }^{118}$

Por seu turno, o princípio da razoabilidade, agindo como um limite à discrição na avaliação dos motivos, exige que sejam eles adequáveis, compativeis e proporcionais, de modo que $o$ ato atenda a sua finalidade pública específica. A razoabilidade, na valoração dos motivos e na escolha do objeto, é, em última análise, o único caminho seguro para se ter certeza de que se garantiu a legitimidade da ação administrativa e o primado do senso comum sobre a ineficiência grosseira e a demagogia administrativa. ${ }^{119}$

Em outro trabalho sobre o tema, DIOGO DE FIGUEIREDO MOREIRA NETO afirma que, além da realidade e razoabilidade, outros critérios, mais exigentes e sutis, consentâneos com a complexidade dos desafios das múltiplas atividades exigidas pelo Estado contemporâneo, ampliam os padrões de juridicidade tornando a atividade legítima quanto aos meios (legitimidade corrente) e quanto aos fins (legitimidade teleológica). São eles: eficiência, economicidade e efetividade. ${ }^{120}$

Para o autor, a nova característica da eficiência supera o padrāo de eficácia, de modo que a aptidão para produçāo dos resultados visados "só estará satisfeita quando esses resultados pretendidos forem efetivamente alcançados e qualificados por uma correlação ótima entre os meios empregados e o que efetivamente

\footnotetext{
11- Para HUMBERTO ÁVILA, a razoabilidade pode ser tomada em três acepçóes distintas: como eqüidade, como congruência e como equivalência: "Primeiro, a razoabilidade é utilizada como diretriz que exige a relação das normas gerais com as individualidades do caso concreto, quer mostrando sob qual perspectiva a norma deve ser aplicada, quer indicando em quais hipóteses o caso individual, em virtude de suas especificidades, deixa de se enquadrar na norma geral. Segundo, a razoabilidade é empregada como diretriz que exige uma vinculação das normas jurídicas com o mundo ao qual elas fazem referência, seja reclamando a existência de um suporte empírico e adequado a qualquer ato jurídico, seja demandando uma relação congruente entre a medida adotada e o fim que ela pretende atingir. Terceiro, a razoabilidade é utilizada como diretriz que exige a relaçāo de equivalência entre duas grandezas." Teoria dos princípios: da definiçãc à aplicação dos princípios jurídicos. São Paulo: Malheiros, 2005, p. 102-111.

118 Legitimidade e discricionariedade. Rio de Janeiro: Forense, 1998, p. 53-54.

119 Op. cit., p. 57.

120 Juridicidade, pluralidade normativa, democracia e controle social. In: Fundamentos do estado de direito: estudos em homenagem ao Professor Almiro do Couto e Silva. São Paulo: Malheiros, 2005, p. 93.
} 
se logrou". Seguindo essa linha, a economicidade é um critério que deriva da eficiência, pois "resultará da aferível e adequada proporcionalidade dos recursos despendidos aos resultados obtidos". Do mesmo modo, a efetividade também é um critério derivado da eficiência, só que seu âmbito de exigência é mais amplo, uma vez que a "correlação ótima entre os meios empregados e o que efetivamente se logrou passa a ser aferida não apenas in casu, mas tendo em vista o benefício para o conjunto da sociedade, ou seja, considerando se o ato do Poder Público, seja ele normativo, administrativo ou judicial, está produzindo no meio social aqueles efeitos que haviam sido abstratamente e genericamente visados na ordem jurídica". ${ }^{121}$

No mesmo entendimento e a partir de uma analogia com o legislador negativo da jurisdição constitucional, pondera JUAREZ FREITAS ${ }^{122}$ que a vedada inquirição, no controle do ato discricionário, quanto à oportunidade e à conveniência não se confunde com o necessário exame da finalidade (invariavelmente vinculante). Porém, os dois parâmetros se avizinham a ponto de se dever afirmar, na busca de uma imprescindível delimitação técnica das fronteiras conceituais, que o controle haverá de ser o de "administrador negativo", em analogia com o de "legislador negativo", exercido no controle de constitucionalidade das leis e dos atos normativos.

Mais adiante assevera o mesmo autor:

Porque se é certo que o Judiciário não pode dizer, substitutiva e positivamente, como o julgador deveria ter julgado ou positivamente agido, deve ernitir juízo principiológico e finalístico de como não deveria ter julgado ou agjido, ao emitir juízos guiados por aquela discrição, sempre vinculada aos princípios superiores da Administração Pública.

Cabe referir, por oportuno, o entendimento de JESSÉ TORRES PEREIRA JÚNIOR, para quem o controle judicial dos atos da Administração Pública pode ser realizado pela verificação da relação de adequação entre os motivos e os resultados:

o que cabe no controle judicial é a verificação da relação de adequação entre os motivos, a sua avaliação técnica e os resultados. Se a verificação dos resultados, que é o desfecho da ação administrativa, cabe no controle judicial, poderá ser necessário, nas circunstâncias do caso concreto, que este sindique o mérito, sob pena de emitir juízo precário e inconclusivo. A par da possibilidade de mérito também existir na avaliação do objeto (quando inserto no círculo da discrição administrativa) e da finalidade do ato (quando implícito na norma). Não se cuidaria, portanto, de substituir

\footnotetext{
12: Op. cit., p. 95.

122 Os atos administrativos de discricionariedade vinculada aos princípios. Boletim de Direito Administrativo, Rio de Janeiro, $n^{\circ}$ 2, jun. p. 324-337.
} 
a soluçāo administrativa pela judicial, mas, sim, de verificar se aquela foi eficiente e gerou o necessário resultado de interesse público que encerre a demanda pelo controle de modo pertinente e seguro. ${ }^{123}$

Por fim, há quem desenvolva o argumento de um controle na execução das políticas públicas pelo planejamento econômico da atividade, como o faz MARCOS JURUENA VILLELA SOUTO, demonstrando a legitimidade das escolhas, por meio de uma conciliação entre o sistema eleitoral, o sistema econômico e o sistema financeiro. ${ }^{124}$

Para o autor, a idéia de planejamento impõe a racionalização das escolhas públicas, em função das possibilidades, dos custos e da sustentabilidade, a longo prazo, de opções do Estado, que ultrapassam a noção de opção de governo e decisões judiciais varejistas. Por outro lado, dado que o conceito de eficiência econômica (alocativa e produtiva) se revela insuficiente para a fixação de eficiência administrativa, o autor propõe que se deva trabalhar com a noção de eficiência pela subsidiariedade, de modo a se definir precisamente a partilha de competências entre o Estado e a sociedade. Dessa forma, impede-se que o Estado atue ineficientemente onde a sociedade já consegue prover os bens e serviços adequadamente. ${ }^{125}$

Para a jurisprudência do Supremo Tribunal Federal, o controle judicial das políticas públicas é admitido, excepcionalmente, desde que: (i) se trate de políticas definidas no texto constitucional, posto ser tal definição vinculante da ação estatal e limitadora da discricionariedade administrativa; (b) o Estado se omita, total ou parcialmente, no exercício de seus deveres jurídico-sociais de prestações positivas, com vistas à implementação dessas políticas; (c) eventuais carências financeiras ou orçamentárias não escusem a omissão, salvo se comprovado o esgotamento dos meios disponíveis e/ou mobilizáveis para o atendimento às prioridades decorrentes das políticas constitucionais. ${ }^{126}$

Diante das precedentes teorias, representativas das melhores doutrinas sobre o tema, parece inegável que o controle das políticas públicas pelo Poder Judiciário é permitido, devendo até mesmo ser facilitado o acesso à jurisdição a órgãos coletivos intermédios da sociedade, como garantia de legitimidade do poder político, da democracia e do mínimo existencial de direitos sociais aos cidadãos. ${ }^{127}$

123 Controle judicial da administração pública: da legalidade estrita à lógica do razoável. Belo Horizonte: Fórum, 2006, p 55.

124 Neoconstitucionalismo e controle de políticas públicas. In: SOUTO, Marcos Juruena Villela. Direito administrativo em debate - $2^{\text {a }}$ Série. Rio de Janeiro: Lumen Juris, 2007, p. 3-24.

25 Op. cit., p. 15-23.

126 Consulte-se os seguintes acórdãos: RE 410715-5-SP, RE 410715-5-SP, SS 3205-AM, ADPF 45-DF.

12: A noçāo de mínimo existencial é proposta por parte da doutrina como solução para o problema dos custos envolvidos na realizaçāo dos direitos sociais. Um contraponto, portanto, à teoria da reserva do possivel. Sobre o tema consulte-se, por todos, BARCELLOS, Ana Paula de. O mínimo existencial e algumas fundamentaçōes: John Rawls, Michael Walzer e Robert Alexy. In: TORRES, Ricardo Lobo (org.). 
Todavia, o Poder Judiciário não pode descurar no exame das políticas públicas, de uma ponderação razoável e proporcional do impacto de suas decisões sobre os orçamentos públicos, sob pena de transformar o governo do povo em governo de "juízes".

\section{Conclusão}

Os interesses individuais que demandam escala metaindividual passam ao Estado pelo processo de institucionalização do poder. São as concentraçōes de poder que, estabilizadas pelo consenso e pelo costume, levam ao surgimento das instituições políticas. Pelo fenômeno da representação, o poder passa a ser exercido por um ou alguns dos membros do grupo para atuar em nome de todos.

Um interesse metaindividual cometido pelo ordenamento jurídico ao Estado caracteriza um interesse público, gênero que compreende várias modalidades, tais como: interesse geral, interesse difuso e interesse coletivo.

A captação política dos interesses da sociedade é imediata e define a legitimidade, enquanto a positivação jurídica desses interesses é mediata e define a legalidade. As dimensões e funções são bem distintas: o interesse público, antes ou depois de legislado, é sempre padrão de legitimidade, mas só o interesse público legislado alcança o padrão de legalidade. Legalidade e legitimidade convergem, portanto, para atendimento ao interesse público, detalhando e precisando, de várias formas e em vários níveis, o seu conteúdo em uma sociedade organizada.

Como a legitimidade possui uma estreita relação com o poder político, a crise deste reflete invariavelmente na captação dos interesses públicos e na legitimidade de ações governamentais. Assim, a democracia representativa entra em colapso, pois se revela insuficiente como instrumento de legitimação do poder político. Busca-se então uma democracia participativa.

A democracia participativa surge como uma forma de reforçar o controle social (accountability ou responsividade) sobre a atuação estatal e torná-la associada ao papel de efetividade dos direitos fundamentais, objetivos do Estado de Direito em sua acepção material.

Sendo a definição das políticas públicas uma função política do Estado, o direito de participação popular nas funçōes legislativas e administrativas revela-se um

Legitimaçāo dos direitos humanos. Rio de Janeiro: Renovar, 2007. Ainda sobre o tema, FLAVIO GALDINO pondera que, ainda que se aceite a existência de um direito subjetivo fundamental a determinadas prestações positivas que integram o mínimo existencial, essas prestações também encontram-se sujeitas aos recursos econômicos e financeiros disponíveis no momento, salientando o autor que tais prestações devem na verdade receber um tratamento preferencial em relação às que não ostentam tal caráter. $O$ custo dos direitos. In: TORRES, Ricardo Lobo. Legitimaçāo dos direitos humanos. Rio de Janeiro: Renovar, 2007, p. 249. 
eficiente instrumento de incremento da democracia participativa, de legitimidade das escolhas governamentais e do controle das políticas estatais. Ademais, a participação proporciona meios de verificação do correto direcionamento dos recursos, para que sejam aplicados de acordo com as necessidades reais da população.

Além do controle popular pela participação, denota-se que os mecanismos de controle político e financeiro institucionais são instrumentos importantes para se assegurar um eficiente sistema de responsividade mútua entre os Poderes no que tange à legitimidade das políticas públicas.

Porém, é preciso que o controle parlamentar opere de modo mais eficiente e técnico. Nesse ponto, revela-se importante não só a efetividade dos instrumentos de controle da função administrativa e financeira do Executivo. Imperioso se faz que o mandato político de cada parlamentar - instrumento da vontade popular - seja fiel e vinculante ao programa de governo do seu partido, de modo a determinar a coerência do poder político.

De igual modo, deve haver uma relação institucional ética entre os partidos políticos que compõem a base parlamentar do Governo, a fim de que as propostas encaminhadas pelo Chefe do Executivo relacionadas às políticas públicas não incorram em vícios de representação político-partidária.

Quanto ao controle judicial e jurídico de legitimidade das políticas públicas, com exceção da Justiça Eleitoral que possui uma competência bastante limitada materialmente, a atuação do Poder Judiciário tem encontrado no contexto do Estado Democrático de Direito um rápido desenvolvimento, ainda que com forte resistência doutrinária, especialmente no Brasil.

A tendência evidenciada pela análise da doutrina e da jurisprudência é a de que o controle das políticas públicas pelo Poder Judiciário é permitido, inclusive como garantia de legitimidade do poder político, da democracia e do mínimo existencial dos direitos sociais. Entretanto, no exercício do controle, o Poder Judiciário não pode deixar de ponderar, em cada caso concreto, a razoabilidade e proporcionalidade do impacto de suas decisões sobre os orçamentos públicos.

\section{Referências}

ACKERMAN, Bruce. Nós, o povo soberano: fundamentos do direito constitucional. Tradução de Mauro Raposo de Mello. Belo Horizonte: Del Rey, 2006.

AMARAL, Roberto. A Democracia representativa está morta: viva a democracia participativa! In: GRAU, Eros Roberto; GUERRA FILHO, Willis Santiago (Org.). Direito constitucional: estudos em homenagem a Paulo Bonavides. São Paulo: Malheiros, 2003. 
ARAS, Augusto. Fidelidade partidária. a perda do mandato parlamentar. Rio de Janeiro: Lumen Juris, 2006.

ÁVILA, Humberto. Teoria dos princípios: da definição à aplicação dos princípios jurídicos. São Paulo: Malheiros, 2005.

BAPTISTA, Patrícia. Transformações do direito administrativo. Rio de Janeiro: Renovar, 2003.

BARCELLOS, Ana Paula de. Constitucionalizaçāo das políticas públicas em matéria de Direitos Fundamentais: o controle político-social e o controle jurídico no espaço democrático. Revista de Direito do Estado, ano 1, no 3, jul./set. 2006.

BARROSO, Luis Roberto. O estado contemporâneo, os direitos fundamentais e a redefinição da supremacia do interesse público. In: SARMENTO, Daniel (Org.). Interesses públicos versus interesses privados: desconstruindo o princípio de supremacia do interesse público. Rio de Janeiro: Lumen Juris, 2005.

BINENBOJM, Gustavo. Uma teoria do direito administrativo: direitos fundamentais, democracia e constitucionalização. Rio de Janeiro: Renovar, 2006.

BUCCI, Maria Paula Dallari. Políticas públicas e direito administrativo. Revista de Informação Legislativa, Brasília, ano 34, nº 133, jan./mar. 1997.

CAETANO, Marcello. Manual de ciência política e direito constitucional. Coimbra: Almedina, 2003.

COMPARATO, Fábio Konder. Ensaio sobre o juízo de constitucionalidade de políticas públicas. Revista de Informação Legislativa, Brasília, ano 35, n² 138, abr./jun. 1998.

DAL BOSCO, Maria Goretti. Discricionariedade em políticas públicas. Curitiba: Juruá, 2007.

DI PIETRO, Maria Sylvia Zanella. Discricionariedade administrativa na Constituição de 1988. São Paulo: Atlas, 2001.

FIGUEIREDO, Argelina Cheibub. Instituiçōes e política no controle do executivo. Revista de Ciências Sociais, Rio de Janeiro, v. 44, nº 4, 2001.

FIGUEIREDO, Lúcia Valle do. O controle jurisdicional da administração pública. Diálogo Jurídico, Salvador, v. I, nº 2, maio, 2001.

FREITAS, Juarez. Estudos de direito administrativo. São Paulo: Malheiros, 1995.

. Os atos administrativos de discricionariedade vinculada aos princípios. Boletim de Direito Administrativo, Rio de Janeiro, no 2, p. 324-337, jun.

GALDINO, Flávio. O custo dos direitos. In: TORRES, Ricardo Lobo. Legitimação dos direitos humanos. Rio de Janeiro: Renovar, 2007. 
LEAL, Rogério Gasta. Os pressupostos epistemológicos e filosóficos da gestão de políticas públicas no estado democrático de direito: uma perspectiva habermasiana. Revista de Direito Administrativo e Constitucional, Belo Horizonte, ano $4, \mathrm{n}^{\circ} 15$, jan./mar. 2004.

O controle social dos serviços públicos no Brasil como condição de sua possibilidade. Revista de Direito Administrativo e Constitucional, Belo Horizonte, ano $3, n^{\mathrm{o}} 13$, jul./set. 2003.

LOCKE, John. Segundo tratado sobre o governo. São Paulo: Abril, 1973.

MARTINS, Fernando Barbalho. Do direito à democracia: neoconstitucionalismo, princípio democrático e a crise no sistema representativo. Rio de Janeiro: Lumen Juris, 2007.

MAURER, Hartmut. Elementos de direito administrativo alemão. Porto Alegre: Sérgio Fabris, 2000.

MELLO, Celso Antônio Bandeira de. Controle judicial dos atos administrativos. Revista de Direito Público, nº 65, p. 27-38, 1983.

MONTESQUIEU. Do espírito das leis. São Paulo: Abril, 1973.

MOREIRA NETO, Diogo de Figueiredo. Legitimidade e discricionariedade. Rio de Janeiro: Forense, 1998.

. Direito da participação política. Rio de Janeiro: Renovar, 1992.

. Curso de direito administrativo. Rio de Janeiro: Forense, 2006.

- Juridicidade, pluralidade normativa, democracia e controle social. In: Fundamentos do estado de direito: estudos em homenagem ao Professor Almiro do Couto e Silva. São Paulo: Malheiros, 2005.

NOBRE, Marcos. Participação e deliberaçāo na teoria democrática: uma introdução. In: COELHO, Vera Schattan P.; NOBRE, Marcos (Org.). Participação e deliberação: teoria democrática e experiências institucionais no Brasil contemporâneo. São Paulo: 34. ed., 2004.

PEREIRA JÚNIOR, Jessé Torres. Controle judicial da administração pública: da legalidade estrita à lógica do razoável. Belo Horizonte: Fórum, 2006.

PEREZ, Marcos Augusto. A administração pública democrática. Belo Horizonte: Fórum, 2004.

RAMAYANA, Marcos. Direito eleitoral. Niterói: Impetus, 2007.

ROBERT, Cínthia; MAGALHĀES, José Luiz Quadros. Teoria do Estado, democracia e poder local. Rio de Janeiro: Lumen Juris, 2002. 
SILVA, José Afonso da. Curso de direito constitucional positivo. São Paulo: Malheiros, 2007.

SOUTO, Marcos Juruena Villela. Neoconstitucionalismo e controle de políticas públicas. In: SOUTO, Marcos Juruena Villela. Direito administrativo em debate: $2^{\mathrm{a}}$ série. Rio de Janeiro: Lumen Juris, 2007.

TORRES, Ricardo Lobo. Controles da administração financeira. In: MOREIRA NETO, Diogo de Figueiredo (Coord.). Uma avaliação das tendências contemporâneas do direito administrativo. Rio de Janeiro: Renovar, 2003.

ZIPPELIUS, Reinhold. Introdução ao estudo do direito. Traduçāo de Gercélia Batista de Oliveira Mendes. Belo Horizonte: Del Rey, 2006. 